\title{
Disproportionate Contribution of Riparian Inputs to Organic Carbon Pools in Freshwater Systems
}

\author{
Trent R. Marwick, ${ }^{1 *}$ Alberto Vieira Borges, ${ }^{2}$ Kristof Van Acker, ${ }^{1}$ \\ François Darchambeau, ${ }^{2}$ and Steven Bouillon ${ }^{1}$
} ${ }^{1}$ Department of Earth and Environmental Sciences, Katholieke Universiteit Leuven (KU Leuven), Celestijnenlaan $200 E, 3001$ Leuven,
Belgium; ${ }^{2}$ Chemical Oceanography Unit, University of Liège (ULg), Institut de Physique (B5), 4000 Liège, Belgium

\begin{abstract}
A lack of appropriate proxies has traditionally hampered our ability to distinguish riverine organic carbon (OC) sources at the landscape scale. However, the dissection of $\mathrm{C}_{4}$ grasslands by $\mathrm{C}_{3}$-enriched riparian vegetation, and the distinct carbon stable isotope signature $\left(\delta^{13} \mathrm{C}\right)$ of these two photosynthetic pathways, provides a unique setting to assess the relative contribution of riparian and more distant sources to riverine $\mathrm{C}$ pools. Here, we compared $\delta^{13} \mathrm{C}$ signatures of bulk sub-basin vegetation $\left(\delta^{13} \mathrm{C}_{\mathrm{VEG}}\right)$ with those of riverine $\mathrm{OC}$ pools for a wide range of sites within two contrasting river basins in Madagascar. Although $\mathrm{C}_{3}$-derived carbon dominated in the eastern Rianala catchment, consistent with the dominant vegetation, we found that in the $\mathrm{C}_{4}$ dominated Betsiboka basin, riverine OC is disproportionately sourced from the $\mathrm{C}_{3}$-enriched riparian fringe, irrespective of climatic season, even though $\delta^{13} \mathrm{C}_{\mathrm{VEG}}$ estimates suggest as much as $96 \%$ of vegetation cover in some Betsiboka sub-basins may be
\end{abstract}

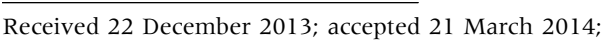
published online 29 April 2014

Electronic supplementary material: The online version of this article (doi:10.1007/s10021-014-9772-6) contains supplementary material, which is available to authorized users.

Author contributions: TRM: lead author, conceived research, performed field sampling, performed sample and data analysis, wrote paper. AVB: conceived research, performed sample analysis, wrote paper. KVA: performed field sampling and sample analysis. FD: performed sample analysis. SB: conceived research, performed field sampling, performed sample and data analysis, wrote paper.

*Corresponding author; e-mail: trentrichard.marwick@ees.kuleuven.be accounted for by $\mathrm{C}_{4}$ biomass. For example, $\delta^{13} \mathrm{C}$ values for river bed OC were on average $6.9 \pm 2.7 \%$ depleted in ${ }^{13} \mathrm{C}$ compared to paired estimates of $\delta^{13} \mathrm{C}_{\mathrm{VEG}}$. The disconnection of the wider $\mathrm{C}_{4}$-dominated basin is considered the primary driver of the under-representation of $\mathrm{C}_{4}$-derived $\mathrm{C}$ within riverine OC pools in the Betsiboka basin, although combustion of grassland biomass by fire is likely a subsidiary constraint on the quantity of terrestrial organic matter available for export to these streams and rivers. Our findings carry implications for the use of sedimentary $\delta^{13} \mathrm{C}$ signatures as proxies for past forest-grassland distribution and climate, as the $\mathrm{C}_{4}$ component may be considerably underestimated due to its disconnection from riverine OC pools.

Key words: Riverine organic carbon; Carbon stable isotopes $\left(\delta^{13} \mathrm{C}\right)$; Tropical rivers; $\mathrm{C}_{4} ; \mathrm{C}_{3}$; Riparian vegetation; Madagascar. 
(OC) pools. Riverine OC pools constitute an amalgam of allochthonous (for example, vegetation and soils) and autochthonous (for example, phytoplankton, benthic algae, aquatic macrophytes) $\mathrm{C}$ sources, with the relative contributions of each to riverine OC pools increasingly disentangled through multi-proxy approaches, such as the use of $\mathrm{C}$ stable isotopes $\left(\delta^{13} \mathrm{C}\right)$ in combination with elemental (for example, C:N) and particulate OC (POC):Chlorophyll a (Chla) ratios (Hamilton and Lewis 1992; Kendall and others 2001; Bernardes and others 2004; Finlay and Kendall 2007; Tamooh and others 2012), and more recently the incorporation of GISbased toolsets (Ballester and others 2013).

In freshwaters with negligible algal production, the predominant driver of riverine $\mathrm{OC} \delta^{13} \mathrm{C}$ signatures is the proportion of organic matter $(\mathrm{OM})$ derived from terrestrial vegetation following the $\mathrm{C}_{3}$ photosynthetic pathway (woody plants and trees, temperate grasses; $\delta^{13} \mathrm{C} \sim-27 \%$ ) compared to the less fractionating $\mathrm{C}_{4}$ photosynthetic pathway (largely tropical and subtropical grasses; $\delta^{13} \mathrm{C} \sim-13 \%$ ) (Hedges and others 1986; Bird and others 1994).

Following from these observations, it has been suggested that marine sedimentary sequences adjacent to major river mouths in the tropics may store extensive records of basin vegetation evolution in the form of terrestrial bulk OC $\delta^{13} \mathrm{C}$ signatures (Mariotti and others 1991). Indeed, others have employed stable isotope techniques to reconstruct paleo-vegetation distribution and paleo-climate regime from $\mathrm{OM}$ buried within various environments, including lacustrine and fluvial deposits (Cerling and others 1988; Mora and others 2002) as well as nearshore (Santschi and others 2007) and offshore (dos Santos and others 2013) marine deposits. Yet, such studies often assume no inherent differences in sediment entrainment or transport between $\mathrm{C}_{3}$ - and $\mathrm{C}_{4}$-derived carbon from source to sink (Wynn and Bird 2007). In fact, notwithstanding the considerable contribution of $\mathrm{C}_{4}$ biomass to sub-Saharan vegetation cover $(\sim 31 \%$; Still and Powell 2010), few studies have identified substantial contribution from $\mathrm{C}_{4}$-derived $\mathrm{C}$ in riverine POC or dissolved OC (DOC) pools of grasslands or savannah grasslands (Mariotti and others 1991; Bird and others 1992; Bird and Pousai 1997; Wynn and Bird 2007; Tamooh and others 2012). The predominantly perennial connection of the $\mathrm{C}_{3}$-enriched riparian zone to active (surface and ground-) water channels, relative to the seasonally parched and disconnected $\mathrm{C}_{4}$-dominated grasslands, has been identified as a key driver of riverine organic $\mathrm{C}$ pools within subtropical and tropical savannah/ grassland ecosystems globally (for example, Congo
[Mariotti and others 1991]; Amazon [Bird and others 1992]; Australian rivers [Bird and Pousai 1997]; Cameroonian rivers [Bird and others 1994, 1998]).

Despite these findings, little systematic analysis of the proportional contribution of these landscape units to riverine organic $\mathrm{C}$ pools has been conducted (for example, Ballester and others 2013). Biomes with distinct spatial segregation of the $\mathrm{C}_{3}$ and $\mathrm{C}_{4}$ photosynthetic pathways should provide a unique scenario with which to assess the proportional contribution of different landscape units to riverine $\mathrm{C}$ pools with the use of $\mathrm{C}$ stable isotopes. Such settings, for example, include tropical and subtropical $\mathrm{C}_{4}$-dominant grasslands (grasslands as defined by Torello-Raventos and others (2013)) partially disconnected from adjacent streams and rivers by a comparatively $\mathrm{C}_{3}$-enriched riparian fringe (for example, see Mariotti and others 1991; Bird and others 1994).

A region where the spatial partitioning of $\mathrm{C}_{3}$ and $\mathrm{C}_{4}$ biomass is astoundingly apparent is within the Hauts-Plateaux grasslands and savannahs of central Madagascar, with estimates that greater than $75 \%$ of the island's surface area is covered by these vegetation biomes (Bond and others 2008). Previous research (Ralison and others 2008) conducted in the Betsiboka basin, which drains much of the Hauts-Plateaux region, reports that $\mathrm{C}$ of $\mathrm{C}_{4}$ origin accounts for $30 \%$ of the riverine DOC and POC pools in the upper part of the estuary, which was considerably lower than expected given estimates that $\mathrm{C}_{4}$ vegetation comprised more than $80 \%$ of basin vegetation land cover. Here, we build on their observations by exploring $\delta^{13} \mathrm{C}$ of riverine POC $\left(\delta^{13} \mathrm{C}_{\mathrm{POC}}\right)$ and DOC $\left(\delta^{13} \mathrm{C}_{\mathrm{DOC}}\right)$ as a function of bulk sub-basin vegetation $\delta^{13} \mathrm{C}\left(\delta^{13} \mathrm{C}_{\mathrm{VEG}}\right)$ and soil $\delta^{13} \mathrm{C}$ signatures in the Betsiboka basin. For comparison, we also report results for an eastern Malagasy drainage basin, the Rianila, characterised by $\mathrm{C}_{3}$ rainforest.

\section{Materials AND Methods}

\section{Basin Characteristics}

\section{The Betsiboka Basin}

The Betsiboka basin drains between 49,000 to $63,000 \mathrm{~km}^{2}$ of central and western Madagascar (Figure 1A), forming north of the Malagasy capital, Antananarivo, at the confluence of the Jabo and Amparihibe rivers (at 938 metres above sea level [m.a.s.l.]) in the Hauts-Plateaux. This region is often cited as one of the most erosive landscapes identified globally, with annual yields of 20,000 to 


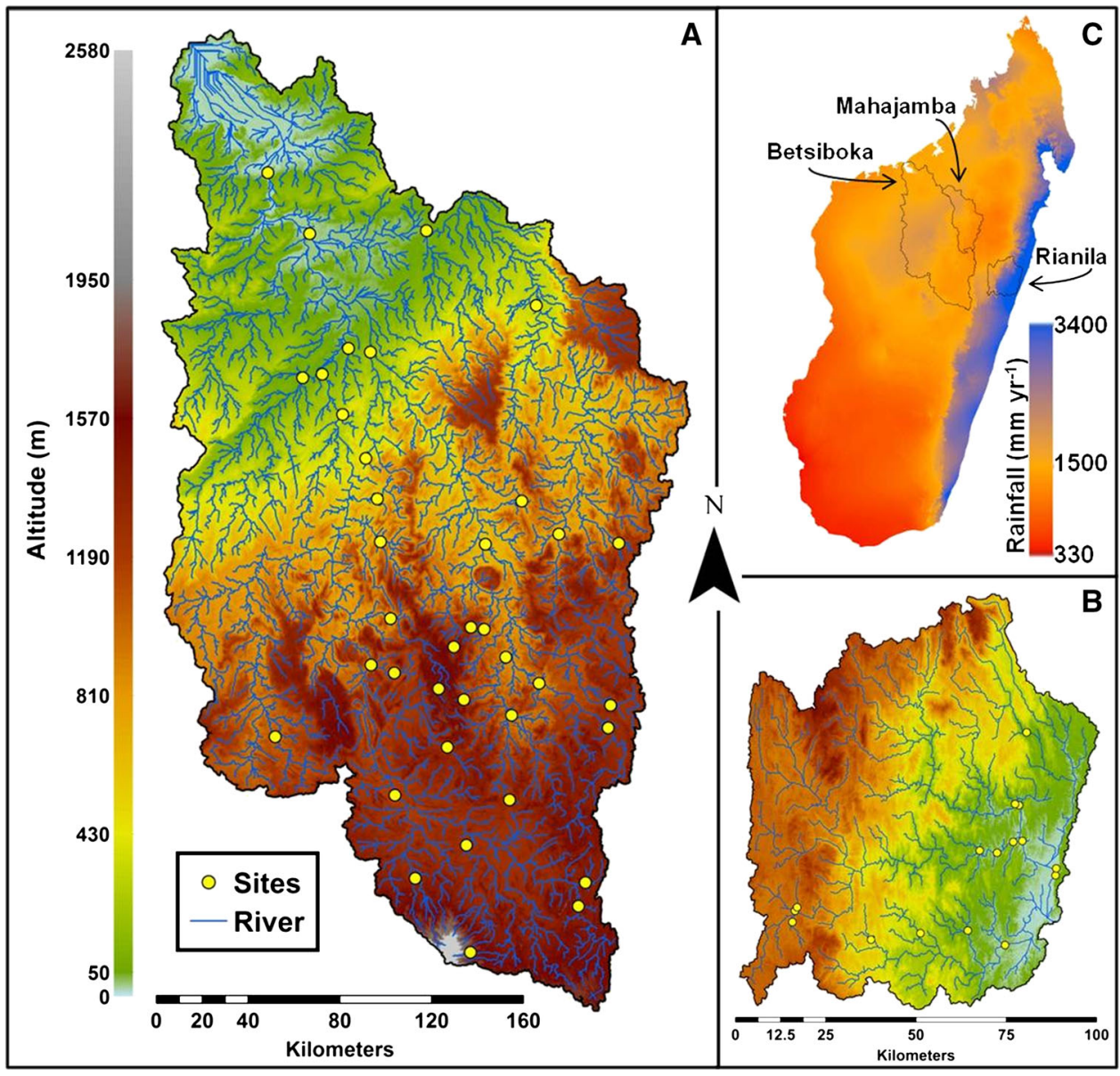

Figure 1. Digital elevation models (DEM) of the two Madagascan study basins: A Betsiboka, and B Rianila. C Shows the strong disparity of annual precipitation between the eastern and western regions of the island. The Mahajamba basin $(\mathbf{C})$ experiences a sporadic connection with the Kamoro River (Betsiboka basin) during elevated discharge periods.
40,000 t km-2 (World Bank 1998; USAID 1998), although Cox and others (2009) suggest more modest yields of $32 \mathrm{t} \mathrm{km}^{-2} \mathrm{y}^{-1}$ estimated from cosmogenic ${ }^{10} \mathrm{Be}$ data of river sediments. Lavakas (meaning 'holes' in Malagasy) are mass failure features common to the Hauts-Plateaux which lead to considerable loss of arable land, elevated suspended and river bed sediment loads (Cox and others 2003, 2004, 2009), and subsequent alluviation of streams, rivers and estuaries (Zavada and others 2009). Relative to their limited spatial extent, lavakas contribute up to $84 \%$ of terrestrial sediment input to Malagasy rivers (Cox and others 2009). At $180 \mathrm{~km}$ downstream of the confluence with the Ikopa River, the principle tributary of the Betsiboka basin, the Betsiboka River flows into the Bombetoka estuary. Average discharge for the Betsiboka and Ikopa rivers, upstream of their confluence, is about 301 and about $77 \mathrm{~m}^{3} \mathrm{~s}^{-1}$, respectively (Figure $2 \mathrm{~A}$ ).

Following the recent classification system proposed by Torello-Raventos and others (2013), the terms grasslands and savannah grasslands, with dominance of $\mathrm{C}_{4}$ grass species, would be appropriate vegetation classifiers for the Hauts-Plateaux region of the Betsiboka basin. Charcoal in regional stratigraphic records suggests natural development and maintenance of the Malagasy grasslands by fire (Burney 1987a, b, c), though the present fire regime is heavily influenced by anthropogenic practices such as pasture management for cattle grazing, with estimates of a quarter to a half of Malagasy grasslands (by land area) are burned annually (Kull 2012). Primary $C_{3}$ vegetation is sparse throughout (approximately 4\% of basin area; see Du Puy and Moat 1996, 1999), with $\mathrm{C}_{3}$-enriched riparian fringes scattered throughout the basin. During the midphase of lavaka evolution (Wells and others 1991; Wells and Andriamihaja 1993, 1997) a $\mathrm{C}_{3}$-enriched forest complex may establish within the lavaka in response to the localised micro-climate (Figure 3 ).

\section{The Rianila Basin}

The Rianila basin drains approximately $7,800 \mathrm{~km}^{2}$ and is an archetypal basin of the eastern slopes of 

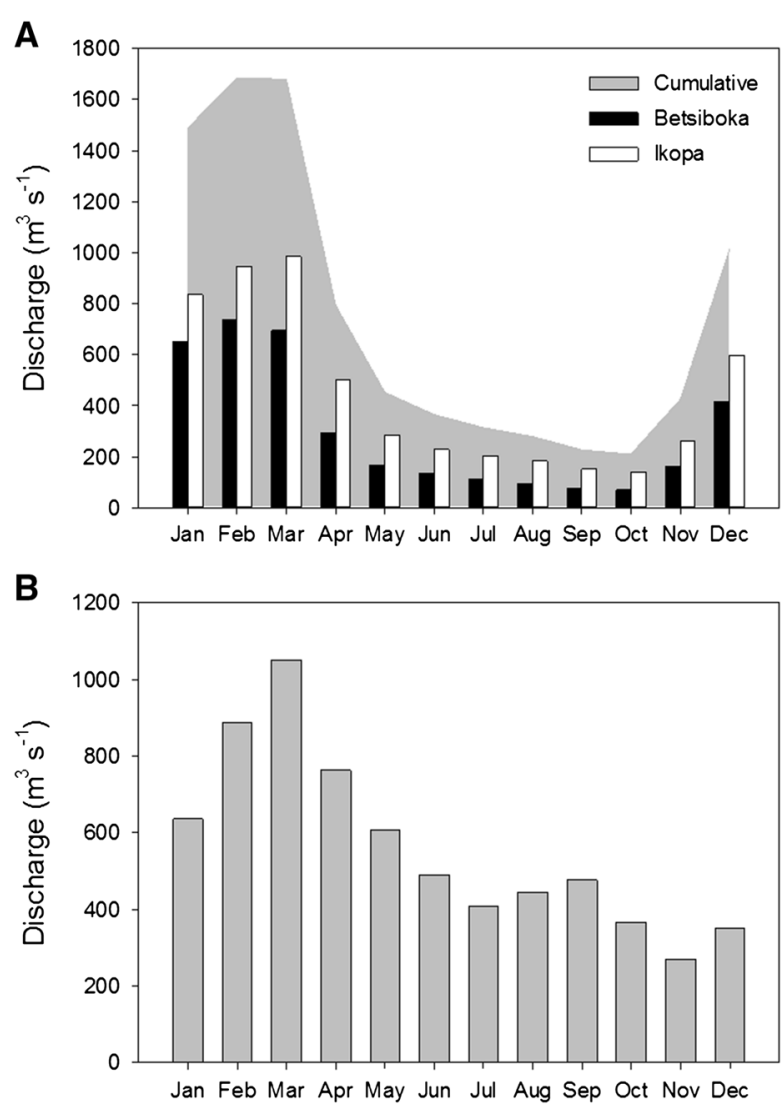

Figure 2. Overview of available historical mean monthly discharge data for A the Betsiboka (at Ambodiroka) and Ikopa (at Bevomanga) rivers, and $\mathbf{B}$ the Rianila at Brickaville. No long-term gauging stations have been established below the junction of the Ikopa with the Betsiboka ( $\sim 180 \mathrm{~km}$ upstream of the outlet) due to the mobile nature of the main channel through the poorly consolidated floodplain sediments, and the wide dispersal of floodwaters over the low lying floodplains following bankfull discharge. Cumulative discharge in $\mathbf{A}$ only represents the sum of Betsiboka and Ikopa discharge upstream of their confluence, and excludes any contribution from the perennial Kamoro River, or from the Mahajamba basin when it is intermittently connected during elevated discharge conditions. Data for the Rianila do not include contributions from the Iaroka River, which joins downstream of Brickaville and drains approximately $1,300 \mathrm{~km}^{2}$ of the Rianila basin. Data from Chaperon and others (1993).

Madagascar (Figure 1B), rising in the Betsimisaraka Heights at 1510 m.a.s.l. Du Puy and Moat (1996, 1999) approximate $61 \%$ of the Rianila basin is vegetated by low- or mid-latitude humid evergreen primary forest. Due to the north-south orientated ridge segregating eastern from central and western Madagascar, a rain-shadow effect results in considerably elevated annual rainfall in eastern regions relative to the rest of the island (Figure $1 \mathrm{C}$ ).
August to October tend to be the driest months, yet trade-winds from the southeast can provide consistent rainfall throughout these months. Annual precipitation ranges between 2,500 and 3,000 mm, resulting in an average discharge of $408 \mathrm{~m}^{3} \mathrm{~s}^{-1}$ at Brickaville (nt. excludes downstream contribution from the Iaroka basin) (Aldegheri 1972) (Figure $2 \mathrm{~B})$.

\section{Sampling and Analytical Techniques}

Sampling was conducted in the Betsiboka and Rianila basins between July and September 2010 (dry season) and January to February 2012 (wet season). Within the Betsiboka, 43 sites were sampled during the dry season with repeated samples at 33 sites in the wet season, whereas 16 sites were sampled in the Rianila basin during both seasons. Riverine physico-chemical parameters $(\mathrm{pH}$, dissolved oxygen, conductivity) were measured using a combination of a YSI Professional Plus (Pro Plus, Quattro cable bulkhead) and YSI Professional Optical Dissolved Oxygen (Pro ODO) instruments. Calibrations for $\mathrm{pH}$ were performed daily using National Bureau of Standards (NBS) buffers of pH 4 and 7 .

A Niskin bottle was used to gather riverine solute samples $0.5 \mathrm{~m}$ below the surface, or using a rope and bucket when sampling from bridges. For bulk POC concentrations and $\mathrm{C}$ stable isotope composition $\left(\delta^{13} \mathrm{C}_{\mathrm{POC}}\right)$, a known volume of surface water was filtered on $25 \mathrm{~mm} \mathrm{GF/F}$ filters (pre-combusted overnight at $450^{\circ} \mathrm{C}$; nominal porosity $=0.7 \mu \mathrm{m}$ ) and subsequently air dried. Later, filters were exposed to $\mathrm{HCl}$ fumes for at least $4 \mathrm{~h}$ to remove inorganic C (IC), subsequently re-dried and packed in Ag cups. Soil OC samples (0-5 cm layer) were collected within $50 \mathrm{~m}$ of the river, whereas river sediment OC samples were taken with a Van Veen grab. Soil and sediment samples were only gathered during the dry season. These samples were stored immediately in liquid $\mathrm{N}_{2}$ until return to the laboratory, where they were stored at $-20^{\circ} \mathrm{C}$. Samples were later dried and homogenised using a mortar and pestle. A weighed subsample was transferred into a Ag cup to which a $10 \% \mathrm{HCl}$ solution was added to remove carbonates. Samples were then dried at $60^{\circ} \mathrm{C}$ for $24 \mathrm{~h}$ and, if necessary, the $\mathrm{HCl}$ procedure was repeated. Leaf litter samples were collected from select sites in each basin below vegetation visually representative of the area. At some sites in the Betsiboka, separate samples were collected from the riparian fringe and the surrounding $\mathrm{C}_{4}$ grasslands. Litter was air dried in the field and stored in air-tight zip-lock bags, and dried 

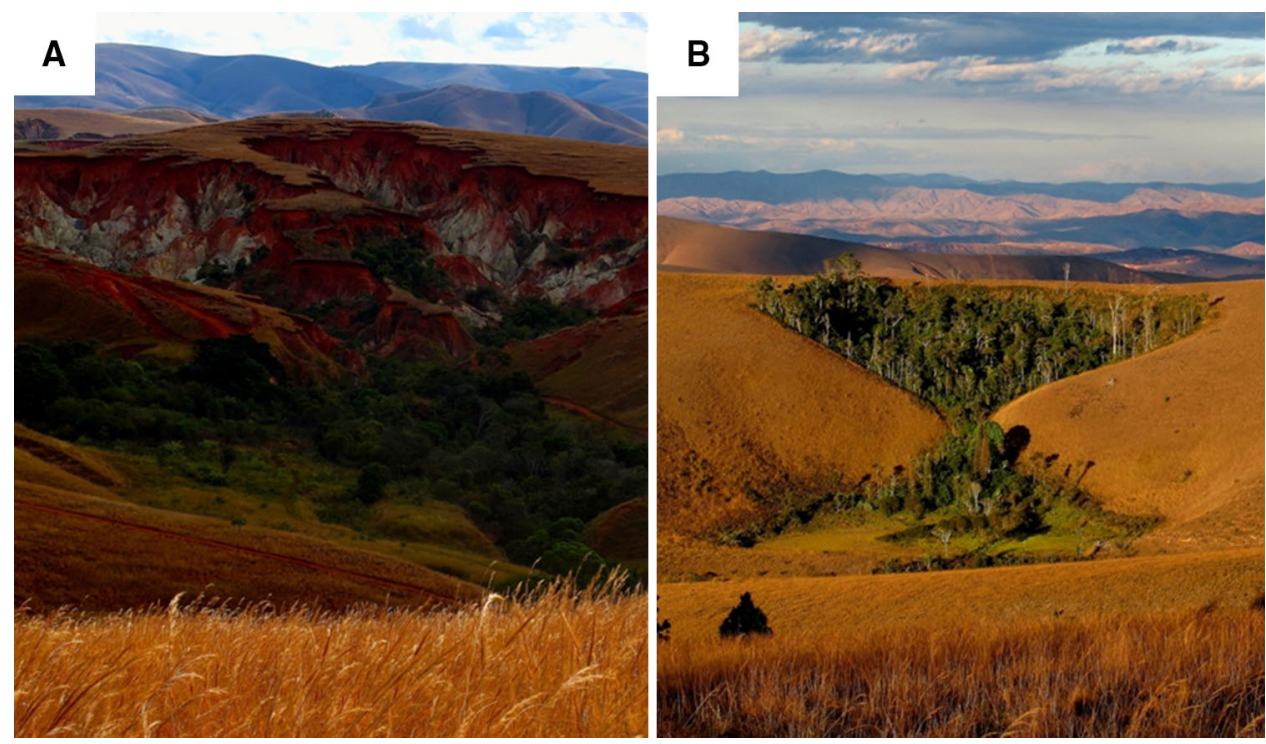

Figure 3. Examples of lavakas in the HautsPlateaux of central Madagascar. A With the collapse of the overlying lateritic soil layer, the more nutrient enriched saprolite layer becomes exposed. As lavakas evolve (B), often a $\mathrm{C}_{3}$ dominant vegetation complex develops in response to increased nutrient and water availability (photos T.R.M.).

at $50^{\circ} \mathrm{C}$ for $24 \mathrm{~h}$ in the laboratory oven. Subsamples were ground and homogenised with a portion transferred to Ag cups ready for analysis. Bulk POC and $\delta^{13} \mathrm{C}_{\mathrm{POC}}, \delta^{13} \mathrm{C}$ of soil $\left(\delta^{13} \mathrm{C}\right.$ soIL $)$ and river bed sediments $\left(\delta^{13} \mathrm{C}_{\mathrm{SED}}\right)$, as well as leaf litter $\delta^{13} \mathrm{C}$ $\left(\delta^{13} \mathrm{C}_{\text {LITTER }}\right)$ were determined on a Thermo elemental analyzer-isotope ratio mass spectrometer (EA-IRMS) system (FlashHT with DeltaV Advantage), and by monitoring the 44,45 and $46 \mathrm{~m} / \mathrm{z}$ signal on the IRMS. Quantification and calibration of $\delta^{13} \mathrm{C}$ data were performed with IAEA-C6 and acetanilide which are internally calibrated against international standards. Reproducibility of $\delta^{13} \mathrm{C}_{\mathrm{POC}}$ measurements was typically better than $\pm 0.2 \%$ whereas relative standard deviations for calibration standards for POC measurements are typically less than $2 \%$ and always less than $5 \%$.

DOC samples were obtained by pre-filtering surface water through pre-combusted GF/F filters $(0.7 \mu \mathrm{m})$, with further filtration through $0.2-\mu \mathrm{m}$ syringe filters, and preserved with $\mathrm{H}_{3} \mathrm{PO}_{4}$ in glass vials with Teflon-coated screw caps. Bulk DOC and $\delta^{13} \mathrm{C}\left(\delta^{13} \mathrm{C}_{\mathrm{DOC}}\right)$ were measured with either a customised Thermo HiperTOC coupled to a Delta $+\mathrm{XL}$ IRMS (Bouillon and others 2006), or by manual injection in a Thermo IsoLink HPLC-IRMS (similar to the method described in Albéric 2011).

Chl $a$ was collected in the field following the procedure of POC above, and used as an index of phytoplankton biomass (Reynolds 2006). Total Chla measurement was achieved by high performance liquid chromatography (HPLC) for dry season samples. The reproducibility of Chla by HPLC has been demonstrated to be within 10\% (Claustre and others 2004). Samples for HPLC analysis were obtained from filtration of $200-1,000 \mathrm{ml}$ on Whatman GF/F filters, of $0.7 \mu \mathrm{m}$ nominal pore size. Filters were immediately stored in liquid $\mathrm{N}_{2}$, and upon return to the lab were kept frozen $\left(a t-25^{\circ} \mathrm{C}\right)$ until further processing. Pigment extraction was carried out in $3 \mathrm{ml}$ of $90 \%$ HPLC grade acetone. After two 15-min sonications separated by an overnight period at $4{ }^{\circ} \mathrm{C}$ in the dark, pigment extracts were processed through a Waters HPLC system comprising a Waters 470 fluorescence detector setup for optimal detection of chlorophyll. The separation was achieved using a $25 \mathrm{~cm}$ Waters Nova-Pak C 18 column and the ternary gradient of Wright (1991). Calibration was achieved using four-point calibration curves established with a Chla standard purchased from DHI, Denmark. Wet season Chla filters, from the Betsiboka basin only, were extracted with $1 \mathrm{ml}$ of $90 \%$ acetone buffered with saturated $\mathrm{MgCO}_{3}$, after which they were incubated overnight at $4^{\circ} \mathrm{C}$. Extracts were centrifuged at 10,000 rpm for $10 \mathrm{~min}$, followed by measurement on a Perkin Elmer Spectrophotometer Lambda20 at 664 and $750 \mathrm{~nm}$ pre- and post-acidification with $750 \mu \mathrm{l}$ of $0.1 \mathrm{M} \mathrm{HCl}$. Wet season Chla concentrations were calculated according to Lorenzen (1967). The majority of sites, however, were below the quantification limit of our methodology, hence we used the quantification limit to provide minimum estimates for POC:Chl $a$ ratios (both expressed in $\mathrm{mg} \mathrm{C}$ ) for the wet season dataset. Chla samples were not collected in the Rianila basin during the wet season due to the unavailability of liquid $\mathrm{N}_{2}$ for sample preservation.

In-situ pelagic primary production (PPP) was determined by filling two 500-ml polycarbonate bottles with surface water and adding $500 \mu \mathrm{l}$ of a

${ }^{13} \mathrm{C}$-enriched bicarbonate solution $\left(>99.8 \%{ }^{13} \mathrm{C}\right.$ $\mathrm{NaH}^{13} \mathrm{CO}_{3}, \sim 40 \mathrm{mg}$ dissolved in $12 \mathrm{ml}$ of surface 
water pre-filtered at $0.2 \mu \mathrm{m})$. Bottles were incubated instream under ambient light and temperature conditions for approximately $2 \mathrm{~h}$, after which a subsample from each bottle was filtered as for POC above. Filters were later exposed to $\mathrm{HCl}$ fumes for $4 \mathrm{~h}$ to remove IC, re-dried and packed in $\mathrm{Ag}$ cups. A separate $12-\mathrm{ml}$ glass headspace vial was filled for measuring dissolved IC $\delta{ }^{13} \mathrm{C}$ following enrichment $\left(\delta^{13} \mathrm{C}_{\text {DIC-PPP }}\right)$ from each incubation bottle with the addition of $10 \mu \mathrm{HgCl}_{2}$ to inhibit further biological activity.

For the analysis of $\delta^{13} \mathrm{C}_{\text {DIC-PPP, a }} 2 \mathrm{ml}$ helium (He) headspace was created, and $\mathrm{H}_{3} \mathrm{PO}_{4}$ was added to convert all DIC species to $\mathrm{CO}_{2}$. After overnight equilibration, part of the headspace was injected in the stream of an elemental analyser-isotope ratio mass spectrometer (EA-IRMS; ThermoFinnigan FlashHT and ThermoFinnigan DeltaV Advantage). The output $\delta^{13} \mathrm{C}$ was corrected for isotopic equilibration between gaseous and dissolved $\mathrm{CO}_{2}$ as described in Gillikin and Bouillon (2007). Analysis of PPP filters followed the procedures outlined above for POC analysis. The PPP rates were calculated based on Hama and others (1983):

$$
\mathrm{PPP}=\frac{\mathrm{POC}_{\mathrm{f}}\left(\%^{13} \mathrm{POC}_{\mathrm{f}}-\%^{13} \mathrm{POC}_{\mathrm{i}}\right)}{t\left(\%^{13} \mathrm{DIC}-\%^{13} \mathrm{POC}_{\mathrm{i}}\right)},
$$

where $\mathrm{POC}_{\mathrm{f}}$ is the particulate $\mathrm{OC}$ after incubation, $\%{ }^{13} \mathrm{POC}_{\mathrm{i}}$ and $\%{ }^{13} \mathrm{POC}_{\mathrm{f}}$ the initial and final (that is, after incubation) percentage ${ }^{13} \mathrm{C}$ of the $\mathrm{POC}, t$ is the incubation time and $\%{ }^{13}$ DIC the percentage ${ }^{13} \mathrm{C}$ of the DIC after the bottles had been spiked. It must be stressed that our PPP data are not depth integrated and are only valid for the upper surface waters, and should be considered to represent the maximum volumetric rates. They are mainly used here, in conjunction with Chla measurements, to constrain an upper limit of autochthonous contribution to riverine OC pools.

All statistical analyses were performed in SigmaPlot v12. Where sites were measured in both dry and wet seasons, paired $t$ tests (hereafter Pt-T) were used to assess significant seasonal changes in the concentrations and $\delta^{13} \mathrm{C}$ of the OC pools, as well as other biogeochemical parameters. Where the seasonal observations were not normally distributed, Pt-T were replaced by Wilcoxon signed rank tests (hereafter SRT).

\section{Results}

\section{Carbon Stable Isotope Composition of Leaf Litter and Soils}

The average $\delta^{13} \mathrm{C}$ of leaf litter OC $\left(\delta^{13} \mathrm{C}_{\text {LITTER }}\right)$ was $-30.2 \pm 0.7 \%$ o $(n=4)$ and $-29.5 \pm 1.1 \%(n=6)$ in the Rianila basin and the riparian zone of the Betsiboka basin, respectively, agreeing with modelled $\delta^{13} \mathrm{C}$ of $\mathrm{C}_{3}$ vegetation for these regions based on Kohn $(2010 ;-30.3 \pm 0.3$ and $-29.3 \pm 0.0 \%$, respectively). Likewise, our data are comparable with those of Crowley and others (2011), who report an average $\mathrm{C}_{3} \delta^{13} \mathrm{C}_{\text {LITTER }}$ of $-31.6 \pm 1.1 \%$ in the eastern Malagasy rainforests and $-28.2 \pm$ $1.3 \%$ for $\mathrm{C}_{3}$ vegetation in the lower Betsiboka basin. The grasslands of the Betsiboka basin were clearly dominated by $\mathrm{C}_{4}$ species (average $\delta^{13} \mathrm{C}_{\text {LITTER }}$ $-12.2 \pm 0.7 \% ; n=9$ ).

These $\mathrm{C}_{3}$ and $\mathrm{C}_{4}$ end-members encapsulate the gradient observed in the $\delta^{13} \mathrm{C}$ of the soil OC $\left(\delta^{13} \mathrm{C}_{\mathrm{SOC}}\right)$ pool in the two basins. In the Betsiboka basin, the $\delta^{13} \mathrm{C}_{\mathrm{SOC}}$ ranged between $-25.8 \%$ (reflecting a predominantly $\mathrm{C}_{3}$ origin) and $-12.0 \%$ (pure $\mathrm{C}_{4}$ origin), whereas $\mathrm{SOC}$ ranged from a pure $\mathrm{C}_{3}(-28.2 \%)$ to mixed $\mathrm{C}_{3}: \mathrm{C}_{4}(-16.9 \%)$ origin in the Rianila basin.

Estimation of Bulk Sub-basin Vegetation $\delta^{13} \mathrm{C}\left(\delta^{13} \mathrm{C}_{\mathrm{VEG}}\right)$ Signatures

Still and Powell (2010) provide a modelled $\mathrm{C}_{4}$ vegetation distribution map for the African continent and the island of Madagascar based on climate datasets, the MODIS Vegetation Continuous Fields (VCF) product (estimate of annual percent cover of herbaceous, tree and bare soil), and the Global Land Cover Map 2000, and converted this to an isoscape using vegetation $\delta^{13} \mathrm{C}$ end-members of $-27 \%$ and $-12 \%$ for pure $\mathrm{C}_{3}$ coverage and pure $\mathrm{C}_{4}$ vegetation, respectively.

With the use of the hydrology tool set of ArcMap 10 and SRTM Void Filled digital elevation data (3 arc-seconds; Earth Explorer, http://earthexplorer. usgs.gov/), we extracted the upstream contributing sub-basin at each sampling location from the Still and Powell (2010) crop-corrected output. Resultant bulk vegetation $\delta^{13} \mathrm{C}\left(\delta^{13} \mathrm{C}_{\mathrm{SP}}\right)$ values were calculated as the average pixel value within the extracted sub-basin (see Supplementary Material). To permit comparison between the $\delta^{13} \mathrm{C}_{\mathrm{SP}}$ estimates and riverine $\delta^{13} \mathrm{C}_{\mathrm{OC}}$ pools, the $\delta^{13} \mathrm{C}_{\mathrm{SP}}$ values were normalised to our $\delta^{13} \mathrm{C}_{\text {LITTER }}$ end-members (that is, Rianila: $100 \% \mathrm{C}_{3}=-30.2 \%, 100 \% \mathrm{C}_{4}=-12.2 \%$ $\left[\mathrm{C}_{4}\right.$ grasses from Betsiboka]; Betsiboka: 100\% $\mathrm{C}_{3}=-29.5 \%, 100 \% \mathrm{C}_{4}=-12.2 \%$ o $)$.

The $\delta^{13} \mathrm{C}_{\mathrm{SP}}$ values were calculated from 28 subbasins, with basin area ranging from 17 to $54,019 \mathrm{~km}^{2}$ and covering a $\delta^{13} \mathrm{C}$ spectrum of -30.0 to $-17.6 \%$. As expected, the Rianila sub-basins were dominated by $\mathrm{C}_{3}$ vegetation, with an average bulk $\delta^{13} \mathrm{C}_{\mathrm{SP}}$ value of $-27.6 \pm 1.7 \%$ (range -22.5 
to $-30.0 \%$ or $57-99 \% C_{3}$ cover, $n=16$ ). The Betsiboka sub-basin average bulk $\delta^{13} \mathrm{C}_{\mathrm{SP}}$ value $(-18.7 \pm 0.6 \%$, range -17.6 to $-19.6 \%$, or 57 and $69 \% \mathrm{C}_{4}$ vegetation cover, $n=12$ ) was more mixed than those of the Rianila, though with less $C_{4}$ influence than was expected from onsite observation.

As originally stipulated by Still and Powell (2010), their outputs were intended for continental analysis of $\mathrm{C}_{4}$ vegetation distribution. Our attempt here to apply them on a regional to local scale highlights one issue with the climatic constraint used to identify areas of potential $\mathrm{C}_{4}$ land cover. Model output is limited in the upper- to mid-basin of the Betsiboka, where a broad region identified in the field, and confirmed through satellite imagery, to be dominated by $\mathrm{C}_{4}$ grasslands has been classified as pure $\mathrm{C}_{3}$ by Still and Powell (2010). We believe this to be a factor of the perennially cool climate of the central highlands not meeting the $\mathrm{C}_{4}$ bioclimatic conditions constraining the model output. Differences in $\mathrm{C}_{3}$ and $\mathrm{C}_{4}$ quantum yield, the ratio of moles of $\mathrm{CO}_{2}$ assimilated relative to moles of photosynthetic active radiation absorbed by a leaf when photosynthesis is limited by low light conditions (Ehleringer and Björkman 1977; Collatz and others 1998), is a key control on the distribution and ecological sorting of the two photosynthetic pathways (Ehleringer 1978). Measured temperatures where the quantum yield of $\mathrm{C}_{3}$ and $\mathrm{C}_{4}$ photosynthesis are equivalent (that is, the crossover temperature), vary from of 16 to $24^{\circ} \mathrm{C}$ (Ehleringer and others 1997), with Still and Powell (2010) using a crossover temperature of $21^{\circ} \mathrm{C}$. Yet Antananarivo, situated in the upper BetsibokaIkopa basin, experiences average annual monthly temperatures of no higher than $21^{\circ} \mathrm{C}$, placing this region outside of the climatic constraints identifying areas of potential $\mathrm{C}_{4}$ land cover. We suggest that a lower crossover temperature may be required to adequately model regional $\mathrm{C}_{4}$ distribution in the Malagasy Hauts-Plateaux, where average monthly temperatures remain below $21^{\circ} \mathrm{C}$ year-round yet $\mathrm{C}_{4}$ grasslands spatially comprise a significant portion of basin vegetation cover.

For these reasons, we developed our own satellite image-based estimate of $\mathrm{C}_{3}$ and $\mathrm{C}_{4}$ distribution
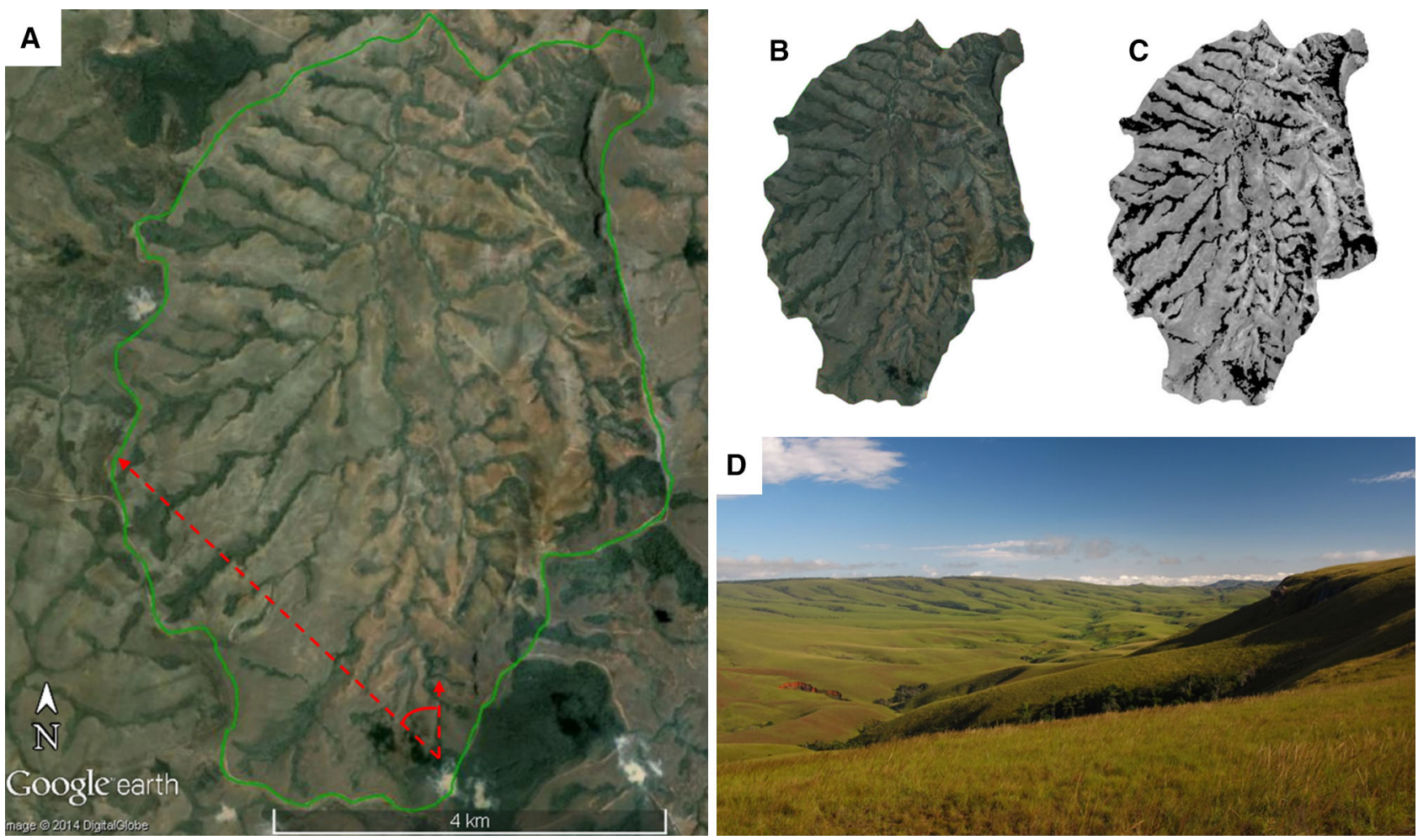

Figure 4. Illustration of the approach used to calculate $\delta^{13} \mathrm{C}_{\mathrm{SBE}}$ values for select sub-basins of the Betsiboka basin. A Overview of the sub-basin of site B38 $\left(36 \mathrm{~km}^{2}\right)$, showing the sub-basin area (green polygon). B Site B38 sub-basin extracted and $\mathbf{C}$ converted to greyscale. $\mathrm{C}_{3}$ vegetation $\left(\delta^{13} \mathrm{C}_{\text {LITTER }}=-29.5 \%\right)$ is classified by black pixels, with all other pixels classified as $\mathrm{C}_{4}$ vegetation $\left(\delta^{13} \mathrm{C}_{\mathrm{LITTER}}=-12.2 \%\right)$. D $\mathrm{C}_{4}$ grasses typically dominate the undulating valleys of the mid-basin Betsiboka, with $\mathrm{C}_{3}$ vegetation confined to the perennially moist soils of the riparian zone and old lavaka depressions (field-of-view is indicated by the red arrows in A). See Supplementary Materials for detailed techniques and similar examples for other sub-basins (Data sourced from Google Earth with data provided by DigitalGlobe). 
$\left(\delta^{13} \mathrm{C}_{\mathrm{SBE}}\right)$ for a selection of the Betsiboka sub-basins. Satellite imagery of 21 sub-basins was extracted from Google Earth Pro (see Supplementary Material). Full sub-basin area was extracted for eight sub-basins (for example, Figure 4), whereas variation in image quality and decreased image resolution at larger scales necessitated the need to extract singular or multiple quadrants representative of total vegetation for the remaining sub-basins (see Supplementary Material). Satellite imagery was subsequently converted to greyscale, followed by increases in gamma correction and contrast, with resultant black pixels classified as $\mathrm{C}_{3}$ cover $\left(\delta^{13} \mathrm{C}_{\text {LITTER }}=-29.5 \%\right.$ o $)$ and all remaining pixels classified as $\mathrm{C}_{4}$ cover $\left(\delta^{13} \mathrm{C}_{\text {LITTER }}=-12.2 \%\right)$, with the sum average pixel value used to estimate the sub-basin $\delta^{13} \mathrm{C}_{\mathrm{SBE}}$ signature.

Bulk $\delta^{13} \mathrm{C}_{\mathrm{SBE}}$ estimates ranged between -22.8 and $-12.9 \%$ (average $\quad \delta^{13} \mathrm{C}_{\mathrm{SBE}} \quad 14.7 \pm 2.2 \%$, $n=21)$. Where paired $\delta^{13} \mathrm{C}_{\mathrm{SP}}$ and $\delta^{13} \mathrm{C}_{\mathrm{SBE}}$ values were estimated, $\delta^{13} \mathrm{C}_{\mathrm{SBE}}$ values were significantly (Pt-T: $P<0.001)$ enriched in ${ }^{13} \mathrm{C}(+4.8 \pm 0.9 \%$, $n=4)$. This leads us to suspect that the $\delta^{13} \mathrm{C}_{\mathrm{SP}}$ values in the Betsiboka underestimate $\mathrm{C}_{4}$ vegetation cover, likely due to differences in pixel resolution between the Still and Powell (2010) output and our $\delta^{13} \mathrm{C}_{\mathrm{SBE}}$ technique. Based on our $\delta^{13} \mathrm{C}_{\text {LITTER }}$ end-members in the Betsiboka basin, $\delta^{13} \mathrm{C}_{\mathrm{SBE}}$ values estimate $\mathrm{C}_{4}$ plants may account for up to $96 \%$ of land cover within some sub-basins. Consideration of implicit errors of this method is briefly discussed in the Supplementary Materials.

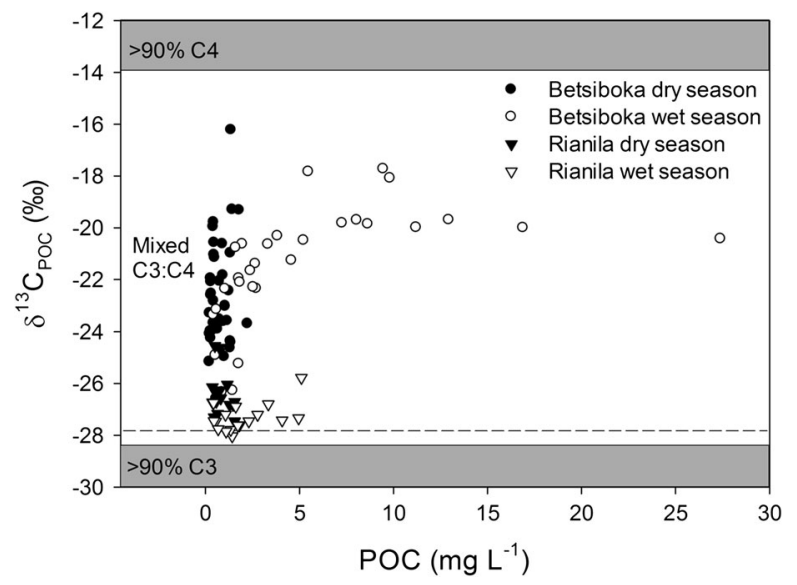

Figure 5. Carbon stable isotope signatures of riverine POC $\left(\delta^{13} C_{\mathrm{POC}}\right)$ as a function of POC concentrations in the Betsiboka and the Rianila basins. Grey shading represent bounds for $90 \% \mathrm{C}_{3}\left(\delta^{13} \mathrm{C}_{\text {LITTER }}=-28.4 \%\right.$ o $)$ vegetation in the Rianila basin and $90 \% \quad \mathrm{C}_{4} \quad\left(\delta^{13} \mathrm{C}_{\text {LITTER }}=-13.9 \%\right)$ vegetation for both the Rianila and Betsiboka basins, whereas the horizontal dashed line represents $90 \% \quad C_{3}$ $\left(\delta^{13} \mathrm{C}_{\text {LITTER }}=-27.8 \%\right.$ oo $)$ vegetation in the Betsiboka basin.

\section{Bulk Riverine Carbon Concentrations and Carbon Stable Isotope Compositions}

As could be expected, given the swath of grasslands covered by lavakas and the resultant sediment entrainment from these erosional features, streams and rivers in the Betsiboka basin were seasonally more sediment-laden than streams and rivers within the more heavily forested Rianila basin. Bulk TSM concentrations in the Betsiboka were significantly higher (SRT: $P<0.001, n=28$ ) during the wet season (range $2.1-3,589.5 \mathrm{mg} \mathrm{l}^{-1}$, average $464.0 \pm 769.3 \mathrm{mg} \mathrm{l}^{-1}, n=29$ ) than during the dry season (range $0.8-128.1 \mathrm{mg} \mathrm{l}^{-1}$, average $36.8 \pm 40.3 \mathrm{mg} \mathrm{l}^{-1}, n=38$ ), and whilst less variability occurred between seasons in the Rianila basin than the Betsiboka, bulk TSM concentration was also significantly elevated (SRT: $P=0.011$, $n=16$ ) during the wet season (range 3.6$103.2 \mathrm{mg} \mathrm{l}^{-1}$, average $32.4 \pm 32.9 \mathrm{mg} \mathrm{l}^{-1}, n=16$ ) than during the dry season (range $2.0-31.8 \mathrm{mg} \mathrm{l}^{-1}$, average $\left.14.5 \pm 9.0 \mathrm{mg} \mathrm{l}^{-1}, n=16\right)$.

Bulk riverine POC in the Betsiboka was significantly higher (SRT: $P<0.001, n=28$ ) during the wet season (range $0.4-27.4 \mathrm{mg} \mathrm{C} \mathrm{I}^{-1}$, average $\left.5.5 \pm 6.0 \mathrm{mg} \mathrm{Cl}^{-1}, n=29\right)$ than the dry season (range $0.2-2.2 \mathrm{mg} \mathrm{l}^{-1}$, average $0.8 \pm 0.5 \mathrm{mg} \mathrm{l}^{-1}$, $n=38$ ), and was represented by $\delta^{13} \mathrm{C}$ ranges of -26.3 to -17.7 and -26.6 to $-16.2 \%$, respectively (Figure 5). The slight, yet significant $(P=0.001$, $n=28)$, difference in $\delta^{13} C_{\text {POC }}$ between dry season

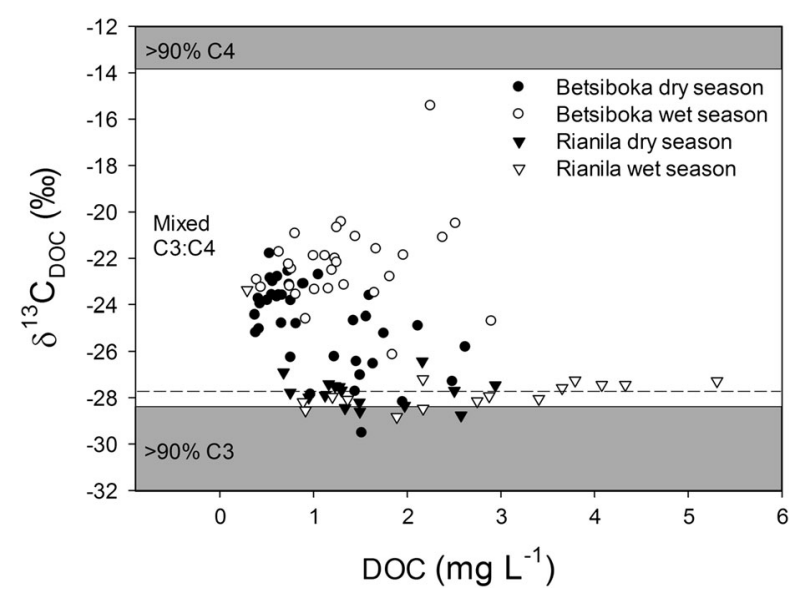

Figure 6. Carbon stable isotope signatures of riverine DOC $\left(\delta^{13} \mathrm{C}_{\mathrm{DOC}}\right)$ as a function of DOC concentrations in the Betsiboka and the Rianila basins. Grey shading represent bounds for $90 \% \mathrm{C}_{3}\left(\delta^{13} \mathrm{C}_{\text {LITTER }}=-28.4 \%\right)$ vegetation in the Rianila basin and $90 \% \mathrm{C}_{4}\left(\delta^{13} \mathrm{C}_{\text {LITTER }}=\right.$ $-13.9 \%$ ) vegetation for both the Rianila and Betsiboka basins, whereas the horizontal dashed line represents $90 \%$ $\mathrm{C}_{3}\left(\delta^{13} \mathrm{C}_{\text {LITTER }}=-27.8 \%\right)$ vegetation in the Betsiboka basin. 
$(-22.7 \pm 2.0 \% \quad n=38)$ and wet season $(-21.4 \pm 2.3 \%, n=29)$ suggests that an increasing quantity of riverine $\mathrm{OC}$ is sourced from $\mathrm{C}_{4}$ grasslands during the wet season. Likewise, increased contribution from these landscape units would account for the marginally, yet again significantly, elevated DOC concentrations (Pt-T: $P=0.002$, $n=28$ ) and $\delta^{13} \mathrm{C}$ signatures (SRT: $P<0.001$, $n=28$ ) observed during the wet season (bulk DOC range $0.4-2.9 \mathrm{mg} \mathrm{C} \mathrm{l}^{-1}$, average $1.3 \pm 0.6 \mathrm{mg} \mathrm{Cl}^{-1}$; $\delta^{13} \mathrm{C}_{\text {DOC }}$ range -26.2 to $-15.4 \%$, average $\delta^{13} \mathrm{C}_{\mathrm{DOC}}$ $-22.3 \pm 1.9 \% ; n=29$ ) relative to dry season (bulk DOC range $0.4-2.6 \mathrm{mg} \mathrm{C} \mathrm{l}^{-1}$, average $1.1 \pm 0.6 \mathrm{mg} \mathrm{C} \mathrm{l}^{-1} ; \delta^{13} \mathrm{C}_{\mathrm{DOC}}$ range -29.5 to $-21.8 \%$, average $\delta^{13} \mathrm{C}_{\mathrm{DOC}}-24.8 \pm 1.8 \%, n=38$ ) (Figure 6).

Significantly elevated concentrations of POC (Pt-T: $P=0.014, n=16$ ) and DOC (Pt-T: $P=0.018, n=16$ ) were also observed in the streams and rivers of the Rianila basin during the wet season (POC: range 0.4$5.1 \mathrm{mg} \mathrm{Cl}^{-1}$, average $2.1 \pm 1.6 \mathrm{mg} \mathrm{C}^{-1}, n=16$; DOC: range $0.3-5.3 \mathrm{mg} \mathrm{Cl}^{-1}$, average $2.6 \pm$ $\left.1.4 \mathrm{mg} \mathrm{C} \mathrm{l}^{-1}, n=16\right)$ compared to the dry season (POC: range $0.4-1.8 \mathrm{mg} \mathrm{C} \mathrm{l}^{-1}$, average $0.9 \pm$ $0.5 \mathrm{mg} \mathrm{C} \mathrm{l}^{-1}, n=16$; DOC: range $0.7-2.9 \mathrm{mg} \mathrm{Cl}^{-1}$, average $1.6 \pm 0.7 \mathrm{mg} \mathrm{Cl}^{-1}, n=16$ ) (Figures 5, 6). Contrary to the enrichment observed in the Betsiboka basin, and evident from the dominance of $\mathrm{C}_{3}$ vegetation within the Rianila basin, riverine POC was significantly ${ }^{13} \mathrm{C}$-depleted (Pt-T: $P=0.002, n=16$ ) during the wet season (range -28.0 to $-25.8 \%$, average $-27.3 \pm 0.6 \%, n=16$ ) relative to dry season POC (range -27.6 to $-24.6 \%$, average $-26.5 \pm$ $0.9 \%, n=16$ ) in the Rianila basin. We speculate this may be attributed to an increased contribution of POC sourced from the wider Rianila basin (that is, less disturbed $\mathrm{C}_{3}$ forest), where there is less influence of human settlement (for example, logging of forest, agriculture, roads) on basin vegetation distribution. No significant seasonal shift in riverine DOC origin was found in the Rianila basin (wet season $\delta^{13} \mathrm{C}_{\mathrm{DOC}}$ range -28.8 to $-23.4 \%$, average $-27.6 \pm 1.2 \%$, $n=16$; dry season $\delta^{13} \mathrm{C}_{\mathrm{DOC}}$ range -28.8 to $-26.4 \%$, average $-27.8 \pm 0.6 \%, n=16$ ).

\section{Indicators of In-Situ Aquatic Production}

Pelagic primary production in the Betsiboka basin during the dry season was generally negligible,

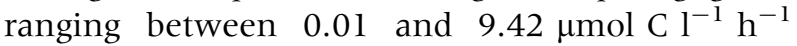

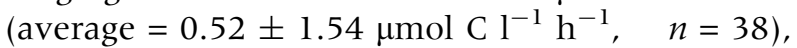
with all but three sites recording PPP rates

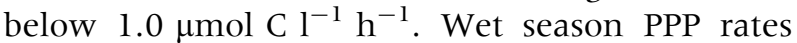
were not significantly different, ranging between

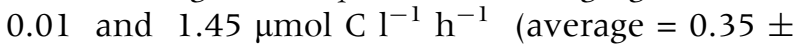

$\left.0.35 \mu \mathrm{mol} \mathrm{C} \mathrm{l}^{-1} \mathrm{~h}^{-1}, \quad n=29\right)$. Despite low PPP rates in the Rianila across both seasons, PPP increased significantly (Pt-T: $P \leq 0.001, n=14$ ) during the wet season, with a range between 0.01 and $0.22 \mathrm{C} \mathrm{l}^{-1} \mathrm{~h}^{-1}$ (average $=0.07 \pm 0.06 \mu \mathrm{mol}$ $\left.\mathrm{C}^{-1} \mathrm{~h}^{-1}, n=15\right)$ during the dry season and 0.07 to $0.45 \mathrm{C} \mathrm{l}^{-1} \mathrm{~h}^{-1}$ (average $=0.20 \pm 0.12 \mu \mathrm{mol} \mathrm{C} \mathrm{l^{-1 }}$ $\left.\mathrm{h}^{-1}, n=15\right)$ in the wet season.

Dry season mg POC: mg Chla ranged from 173 to 6,843 (average $=2,019 \pm 1,241$ ) and 1,280 to 4,468 (average $=2,768 \pm 963$ ) in the Betsiboka and Rianila basins, respectively. All wet season Chla measurements from the Betsiboka basin were below the limit of quantification, which resulted in minimum values for mg POC: mg Chla consistently above 1,000, except at B38 where the mg POC: mg Chla was 487.

\section{Discussion}

\section{Dominance of Terrestrial Organic Carbon}

The major terrestrial OC sources considered here are $\mathrm{C}_{3}$ and $\mathrm{C}_{4}$ vegetation, though it is necessary to account for or dismiss the contribution from autochthonous sources, including phytoplankton, benthic algae and aquatic macrophytes, which in certain conditions can contribute substantially to riverine OC pools in tropical systems (Lewis and others 2001; Davies and others 2008). Several lines of evidence indicate that terrestrial carbon sources dominate in the basins studied here, and that any contributions from aquatic producers are minimal and would not bias our interpretations. First, the PPP rates were extremely low and showed little seasonal variation. Only downstream from the junction of the Ikopa with the Betsiboka, where channel slope rapidly decreases and the channel broadens, does PPP marginally increase (2.1-9.4 $\left.\mu \mathrm{mol} \mathrm{C}^{-1} \mathrm{~h}^{-1}\right)$. Second, low POC:Chla ratios ( 40; see Abril and others 2002, and references therein) are indicative of large phytoplankton contributions to the POC pool, with increasingly larger ratios where terrestrial-derived POC becomes more dominant (Finlay and Kendall 2007; Findlay 2010). Our data suggest negligible contribution of Chla to riverine POC, with mg POC:mg Chla consistently above 1,000 in both basins, and only once was the mg POC:mg Chl $a$ less than 200 (in the main channel of the lower Betsiboka during dry season). Third, the Malagasy streams and rivers here were generally marked by low concentrations of ammonium $\left(\mathrm{NH}_{4}{ }^{+}\right)$, nitrate $\left(\mathrm{NO}_{3}{ }^{-}\right)$and phosphate $\left(\mathrm{PO}_{4}{ }^{3-}\right)$ across the two campaigns (Rianila median values: $\mathrm{NH}_{4}{ }^{+}=6.3 \mu \mathrm{mol} \mathrm{l} l^{-1}, \mathrm{NO}_{3}{ }^{-}=3.0 \mu \mathrm{mol} \mathrm{l}{ }^{-1}$, 
$\mathrm{PO}_{4}{ }^{3-}=0.6 \mu \mathrm{mol} \mathrm{l}^{-1}$; Betsiboka median values: $\mathrm{NH}_{4}{ }^{+}=4.1 \mu \mathrm{mol} \mathrm{l}{ }^{-1}, \mathrm{NO}_{3}{ }^{-}=2.7 \mu \mathrm{mol} \mathrm{l} l^{-1}, \mathrm{PO}_{4}{ }^{3-}=$ $0.8 \mu \mathrm{mol} \mathrm{l}^{-1}$; data not presented in detail; see also Figure 9 of Marwick and others 2014).

The absence of substantial aquatic primary production can likely be ascribed to low nutrient and light conditions, through shading, for example, in the forested headwaters of the Rianila, or due to the high turbidity in the Betsiboka basin. Shading by riparian fringe vegetation has long been identified as an over-riding control on instream primary productivity (Feminella and others 1989; Boston and Hill 1991), and more recently in freshwaters of the tropics specifically (Davies and others 2008), whereas increased turbidity and light attenuation within the water column of larger rivers can also limit instream primary production (Vannote and others 1980). We speculate the latter may also be applicable to the grassland headwaters of the Betsiboka basin, which receive significant suspended sediment inputs from lavakas. Additionally, it has also been shown that, even where riparian shading effects are negligible, nutrients may impart substantial influence on instream primary productivity (Peterson and others 1983; Pringle and others 1986; Winterbourn 1990; Hill and others 1995; Borchardt 1996; Mosisch and others 1999), with evidence for nitrogen being the primary limiting nutrient for algal growth previously found in subtropical (Mosisch and others 2001) and tropical freshwaters (Downing and others 1999; Flecker and others 2002; Udy and Dennison 2005). No aquatic macrophytes were observed during the study, an observation consistent with Elouard (2001) who reports few macrophytes for Malagasy freshwaters as a whole. From the above reasoning, we speculate there is negligible contribution of autochthonous $\mathrm{C}$ to riverine OC pools of these Malagasy basins, and hypothesise that $\delta^{13} \mathrm{C}$ signatures of riverine particulate and DOC will be largely representative of the relative proportion of $\mathrm{C}$ originating from the two terrestrial end-members, that is, $\mathrm{C}_{3}$ and $\mathrm{C}_{4}$ vegetation.

\section{Disproportionate Contribution of Riparian OM to Riverine OC Pools}

A clear pattern emerges when considering the combined data from both basins, with riverine DOC, POC and sediment OC all consistently more ${ }^{13} \mathrm{C}$-depleted than expected across the $\mathrm{C}_{3}-\mathrm{C}_{4}$ gradient. These relationships are evident irrespective of whether riverine OC fractions are explored as a function of estimated bulk vegetation $\delta^{13} \mathrm{C}$ (Figure $7 \mathrm{~A}-\mathrm{C}$ ) or soil $\delta^{13} \mathrm{C}$ (Figure $8 \mathrm{~A}-\mathrm{C}$ ).
Excluding lesser autochthonous contributions, riverine DOC is sourced from the leaching of plant litter and the degradation of soil OM, whereas the POC fraction, on the other hand, is largely sourced from fragmented plant matter and direct inputs of leaf litter, OM mobilised from surrounding soil profiles, as well as autotrophic production within the freshwaters (Meybeck 1993; Ludwig and others 1996; Finlay and Kendall 2007). Having already

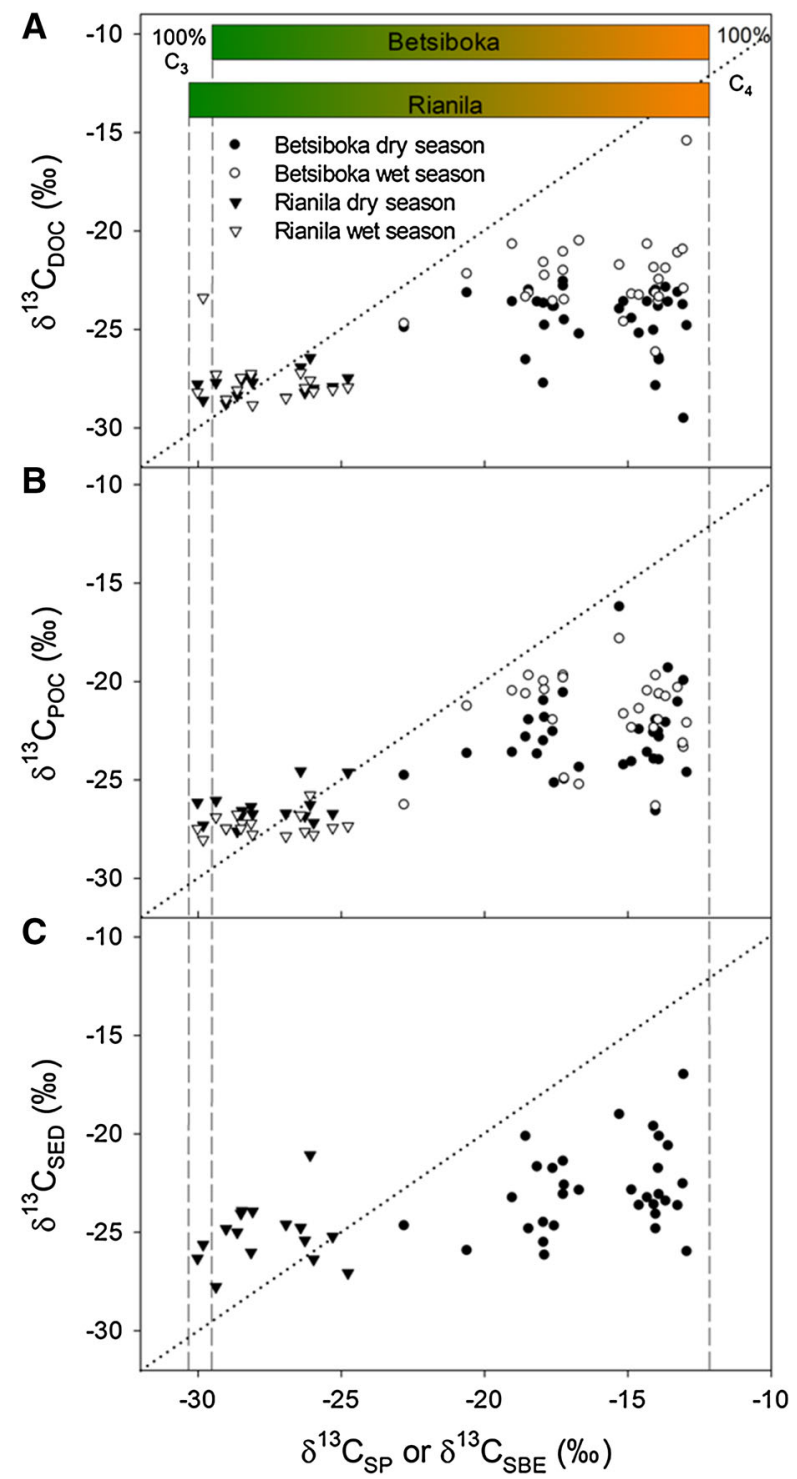

Figure 7. $\delta^{13} \mathrm{C}$ data on major riverine $\mathrm{C}$ pools (A DOC; B POC; $\mathbf{C}$ river sediment) along the gradient of sub-basin bulk vegetation $\delta^{13} \mathrm{C} \quad\left(\delta^{13} \mathrm{C}_{\mathrm{SP}}\right.$ or $\left.\delta^{13} \mathrm{C}_{\mathrm{SBE}}\right)$. Sediment samples were only gathered during the dry season campaign. The dotted line represents a 1:1 relationship. Vertical dashed lines represent $100 \% \mathrm{C}_{3}$ vegetation in the Rianila $\left(\delta^{13} \mathrm{C}_{\text {LITTER }}=-30.2 \%\right)$ and Betsiboka $\left(\delta^{13} \mathrm{C}_{\text {LITTER }}=\right.$ $-29.5 \%)$ and pure $\mathrm{C}_{4}\left(\delta^{13} \mathrm{C}_{\text {LITTER }}=-12.2 \%\right)$ vegetation in both basins. 


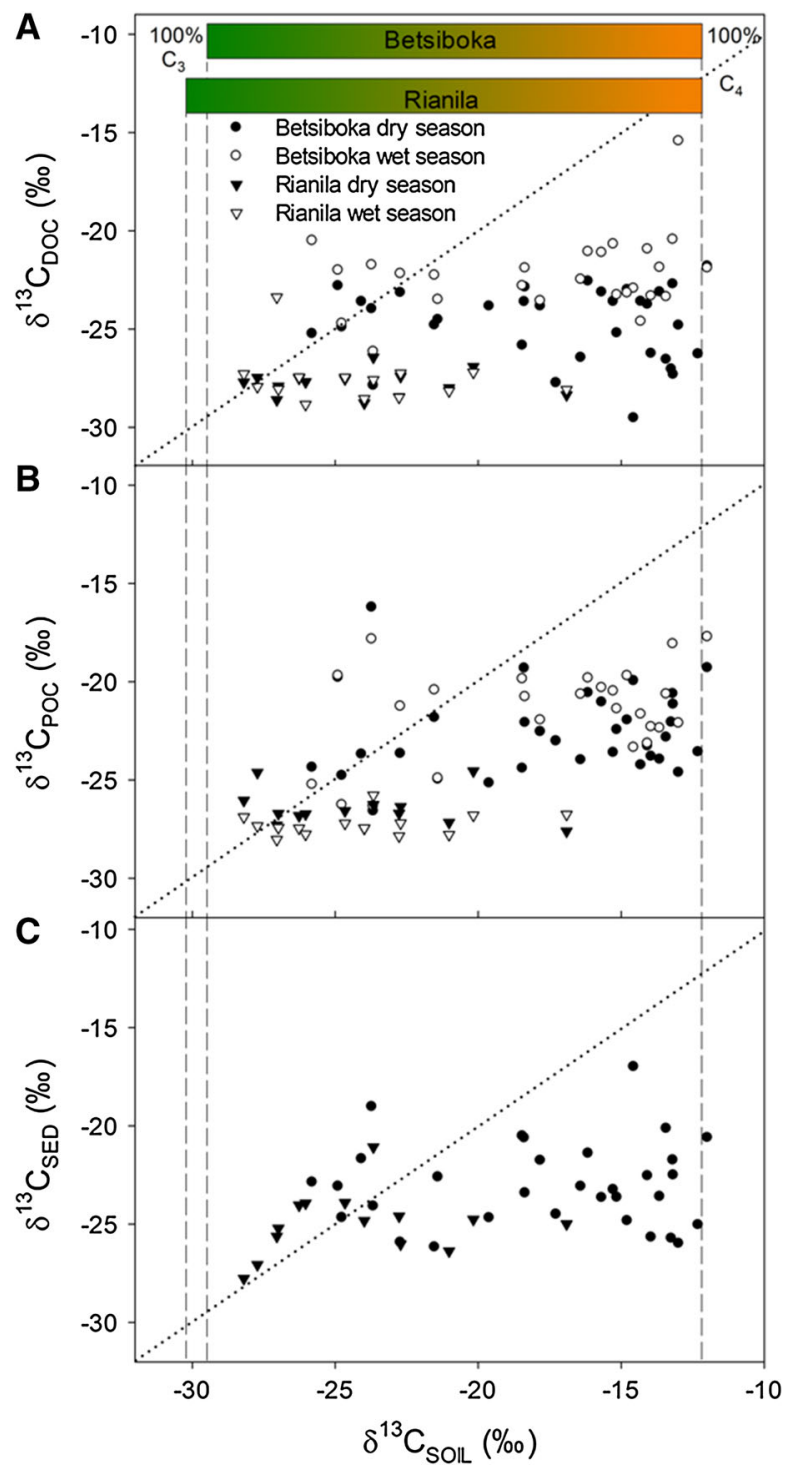

Figure 8. $\delta^{13} \mathrm{C}$ data on major riverine C pools (A DOC; B POC; $\mathbf{C}$ river sediment) along the gradient of sub-basin soil organic carbon $\delta^{13} \mathrm{C}\left(\delta^{13} \mathrm{C}_{\text {SOIL }}\right)$. Soil and sediment samples were only gathered during the dry season campaign. The dotted line represents a 1:1 relationship. Vertical dashed lines represent $100 \% \mathrm{C}_{3}$ vegetation in the Rianila $\left(\delta^{13} \mathrm{C}_{\text {LitTeR }}=-30.2 \%\right)$ and Betsiboka $\left(\delta^{13} \mathrm{C}_{\text {LITTER }}=\right.$ $-29.5 \%)$ and pure $\mathrm{C}_{4}\left(\delta^{13} \mathrm{C}_{\text {LITTER }}=-12.2 \%\right)$ vegetation in both basins.

discounted significant contribution of algal C sources to riverine $\mathrm{OC}$ pools in the Rianila basin, it is unsurprising that riverine DOC and POC $\delta^{13} \mathrm{C}$ values reflect the dominance of $\mathrm{C}_{3}$ vegetation in this system (Figure 7A, B). Additionally, recent radiocarbon measurements of DOC in the Rianila basin during the wet season, including two headwater and one main channel samples, were all ${ }^{14} \mathrm{C}$-enriched $\left(\Delta{ }^{14} \mathrm{C}\right.$ range +81 to $+136 \%$; own unpublished data) and indicate a modern terrestrial $\mathrm{C}_{3}$-enriched DOC source for Rianila streams and rivers.

The relationship between soils and riverine OC in the Rianila basin (Figure 8A, B) is weaker than that discussed above for basin vegetation, though can be expected given that riverine $\delta^{13} \mathrm{C}$ values and $\delta^{13} \mathrm{C}_{\mathrm{VEG}}$ estimates are integrated compositions of $\delta^{13} \mathrm{C}$ from broad areas, whereas $\delta^{13} \mathrm{C}_{\text {SOIL }}$ values are determined from spatially isolated samples. Although $\delta^{13} \mathrm{C}_{\text {soIL }}$ values do highlight the, at times significant (up to $-16.9 \%$ ), presence of $\mathrm{C}_{4}$ biomass within the vicinity of Rianila streams and rivers. We speculate that the presence of this $\mathrm{C}_{4}$ biomass within the riparian fringe and surrounding floodplain, likely associated with the tendency of human settlement and disturbance of the natural vegetation within these areas (including the introduction of $\mathrm{C}_{4}$ crops and invasive species), results in the slight ${ }^{13} \mathrm{C}$ enrichment observed in the riverine POC pool during the dry season. Others have shown that the riparian fringe disproportionately contributes to dry season riverine POC loads in the tropics (Mariotti and others 1991; Bird and others 1992). In the case of the Rianila, elevated rainfall would lead to increased quantities of OM mobilised from the $\mathrm{C}_{3}$-enriched surrounding forests, subsequently lowering the relatively ${ }^{13} \mathrm{C}$-enriched dry season POC signal.

Considering $\delta^{13} \mathrm{C}_{\mathrm{VEG}}$ estimates suggest that $\mathrm{C}_{4}$ biomass accounts for between 39 and $96 \%$ of vegetation cover in the Betsiboka sub-basins, there is no such prominence of $\mathrm{C}_{4}$ derived $\mathrm{C}$ in riverine OC pools (Figure 7A, B). A similar observation has been made for other subtropical and tropical savannah/grassland ecosystems (Mariotti and others 1991; Bird and others 1992, 1998; Bird and Pousai 1997). For example, Mariotti and others (1991) report an average riverine $\delta^{13} \mathrm{C}_{\mathrm{POC}}$ value of $-27.5 \%$ for three savannah dominated tributaries of the Congo River, whereas Bird and others (1992) provide values ranging from -29.9 to $-27.0 \%$ for the cerrado-dominated Araguaia/Tocantins subbasin of the Amazon network. A seasonal fluctuation in riverine $\delta^{13} \mathrm{C}_{\mathrm{POC}}$ of $3.3 \%$ was also identified in the Sanaga River basin by Bird and others (1998) and closely linked to runoff intensity, with the lower $\delta^{13} \mathrm{C}$ values present during the wet season, which is comparable to the average deviation of $1.1 \%$ in streams and rivers of the Betsiboka where we have both dry and wet season $\delta^{13} \mathrm{C}_{\mathrm{POC}}$ data $(n=28)$. A common feature to each of these basins for which $\delta^{13} \mathrm{C}_{\mathrm{POC}}$ values are listed above, including the Betsiboka basin here, is the $\mathrm{C}_{3}$-enriched nature of the riparian fringes. It is generally considered, and re-iterated here through our observations in 
the Betsiboka basin, that the $\mathrm{C}_{3}$-enriched riparian fringe, being in close proximity to the riverbanks, provides disproportionately (relative to land cover) to dry season riverine OC pools, whereas with the advent of the wet season, the increased mobilisation of $\mathrm{OC}$ from the $\mathrm{C}_{4}$-enriched areas farther from the streams and rivers leads to relatively ${ }^{13} \mathrm{C}$-enriched riverine $\mathrm{POC}$ pools (Mariotti and others 1991; Bird and others 1992, 1998; Bird and Pousai 1997).

Although we consider the disconnection of the wider $\mathrm{C}_{4}$-dominated basin from the streams and rivers as the primary driver of the under-representation of $\mathrm{C}_{4}$-derived $\mathrm{C}$ within riverine $\mathrm{OC}$ pools in the Betsiboka, given the history (Burney 1987a, b, c) and prevalence (Kull 2004, 2012) of fire within the grasslands of Madagascar, the effect of terrestrial biomass loss through combustion by fire needs some consideration. Kull (2004) reports as much as one quarter to one half (of land area) of the Malagasy grasslands may be burned annually. Lehsten and others (2009) estimate African wildfires consume approximately $10 \%$ of savannah NPP annually, approximating $0.52-0.59 \mathrm{t} \mathrm{C} \mathrm{ha}^{-1} \mathrm{y}^{-1}$ from Lloyd et al. (2008) estimates of African grassland NPP (see discussion below). Clearly, the preferential loss of $\mathrm{C}_{4}$ derived $\mathrm{C}$ to the atmosphere as $\mathrm{CO}_{2}$ or fine particulate matter by combustion diminishes the quantity available for export to streams and rivers (Menaut and others 1990) and thereby should be considered a subsidiary control of riverine $\mathrm{OC} \delta^{13} \mathrm{C}$ composition.

Where only a single sampling of riverine OC is logistically possible in tropical basins containing significant $\mathrm{C}_{4}$ biomass, due to the large annual range of riverine $\delta^{13} \mathrm{C}_{\mathrm{POC}}$ values, the $\delta^{13} \mathrm{C}$ values of river bed sediments offer a more reliable indication of the average riverine $\delta^{13} \mathrm{C}_{\mathrm{POC}}$ transported in these systems (Bird and Pousai 1997). Although here we replicate riverine OC measurements in the dry and wet season, it is reasonable to assume our data do not capture the total annual variability of riverine POC and, as such, our river bed sediment $\delta^{13} \mathrm{C}$ values may be a more reliable indicator of average riverine $\delta^{13} \mathrm{C}_{\mathrm{POC}}$.

The limited range of $\delta^{13} \mathrm{C}_{\mathrm{SED}}$ values relative to $\delta^{13} \mathrm{C}_{\text {SOIL }}$ values (Figure $8 \mathrm{C}$ ) in both the Rianila (average $\delta^{13} \mathrm{C}_{\mathrm{SED}}-25.1 \pm 1.5 \%, n=16$ ) and Betsiboka (average $\delta^{13} \mathrm{C}_{\text {SED }}-23.0 \pm 2.1 \%, n=37$ ) is normal given that river bed sediments assimilate $\delta^{13} \mathrm{C}$ compositions from a considerably broader area relative to the soil measurements (Bird and Pousai 1997). Whereas $\delta^{13} \mathrm{C}_{\mathrm{SED}}$ values in the Rianila basin were largely reflective of our $\delta^{13} \mathrm{C}_{\mathrm{VEG}}$ estimates (Figure $7 \mathrm{C}$ ), the significant depletion of ${ }^{13} \mathrm{C}$ in river bed sediments of the Betsiboka basin compared to our $\delta^{13} \mathrm{C}_{\mathrm{VEG}}$ estimates (average $\delta^{13} \mathrm{C}_{\mathrm{SED}}-\delta^{13} \mathrm{C}_{\mathrm{VEG}}$ $6.9 \pm 2.7 \%, n=32$ ) confirms the suggestions above that there exists a strong disconnection between the terrestrial $\mathrm{C}_{4}$ and riverine $\mathrm{OC}$ pools. Such a disconnection may lead to gross over-estimation of basin-scale $\mathrm{C}_{3}$ vegetation cover when extrapolated from $\delta^{13} \mathrm{C}$ signatures stored in sedimentary deposits of fluvial origin.

Two regional environmental conditions may complicate our interpretations outlined above. First, if net primary productivity (NPP) in $\mathrm{C}_{3}$-enriched riparian fringes is significantly greater relative to NPP of the surrounding grasslands, it may not be surprising to find an under-representation of $\mathrm{C}_{4}$ sourced $\mathrm{C}$ (relative to land cover) in riverine OC pools. We do not believe the riparian fringe vegetation in the Betsiboka basin constitutes tropical forests, an African biome for which no published field studies estimating NPP exist (Valentini and others 2014), but rather more closely resemble scrub and woodland savannah as defined by Torello-Raventos and others (2013). Employing the NPP estimates provided by Lloyd and others (2008), which cover the transition from grassland to woodland savannah in the tropics, grassland NPP may be between 5.2 and $5.9 \mathrm{t} \mathrm{C} \mathrm{ha}^{-1} \mathrm{y}^{-1}$, which is comparable with the median estimate of $6.2 \pm 1.8 \mathrm{t} \mathrm{C} \mathrm{ha}^{-1} \mathrm{y}^{-1}$ reported by Ciais and others (2011). For open savannah woodland in eastern and southern Africa, Lloyd and others (2008) estimate NPP of 7.8 and $5.1 \mathrm{t} \mathrm{C} \mathrm{ha}^{-1} \mathrm{y}^{-1}$, respectively, and values of 8.8 and $7.1 \mathrm{t} \mathrm{C} \mathrm{ha}^{-1} \mathrm{y}^{-1}$ for eastern and southern savannah woodlands, respectively. It should also be noted that the riparian fringes of the Betsiboka basin are not spatially expansive, and where present often do not extend more than a few tens of metres from the river (see Figure 3; Supplementary Materials). As such, we suspect NPP in the grasslands and riparian fringe of the Betsiboka are within a comparable range, and any differences will have a minor impact on the quantity of terrestrial $\mathrm{C}$ available for export to riverine $\mathrm{C}$ pools from the respective landscape units. Second, $\mathrm{C}_{4}$ agricultural crops, such as sugar cane, may contribute significantly to riverine OC pools (Bunn and others 1997). The area of sugar cane harvest in both the Betsiboka and Rianila basins equates to less than $0.2 \%$ of total basin area (HarvestChoice 2011), and as no major sugar cane agriculture was observed within the vicinity of any of the field sites, we expect it to be a negligible source of $\mathrm{C}_{4}$ carbon to the riverine pools reported here. Whereas, in Malagasy basins paddy rice agriculture, a $\mathrm{C}_{3}$ crop, is often confined to the riparian fringe (Aldegheri 
1964; Benstead and Pringle 2004), and could potentially skew riverine OC $\delta^{13} \mathrm{C}$ values towards the $\mathrm{C}_{3}$ end-member.

\section{Conclusions}

With their strong partitioning of $\mathrm{C}_{3}$ and $\mathrm{C}_{4}$ vegetation at the landscape scale, subtropical and tropical $\mathrm{C}_{4}$-rich grasslands provide the optimum environment to further explore the relative delivery of terrestrial $C$ from different landscape units to river networks, as well as the investigation of trophic linkages between aquatic consumers and riparian carbon sources (for example, Abrantes and others 2013). Our data on the $\delta^{13} \mathrm{C}$ signatures of various riverine OC pools from subtropical basins demonstrate that the $\mathrm{C}_{3}$-enriched riparian vegetation contributes disproportionately to riverine OC pools compared to the spatially dominant, yet seasonally disconnected, $\mathrm{C}_{4}$-dominant grasslands. The prevalence of fire within grassland ecosystems, with consideration they may combust $10 \%$ of annual NPP within this biome type, suggests the prevailing fire regime will also exert significant control over the quantity of grassland $\mathrm{OM}$ available for export to streams and rivers and, ergo, riverine OC $\delta^{13} \mathrm{C}$ values. These observations clearly highlight that the $\delta^{13} \mathrm{C}$ of riverine organic C pools may not be an accurate proxy for extrapolating $\mathrm{C}_{3}$ and $\mathrm{C}_{4}$ vegetation cover of a drainage basin, but appear to be strongly biased towards the dominant photosynthetic pathway of riparian fringe vegetation. Our $\delta^{13} \mathrm{C}$ values of riverine sediments in a basin dominated by tropical grassland indicate that upon deposition these sediments are not representative of the overall vegetation distribution in the contributing drainage basin, and that the analysis of sedimentary $\delta^{13} \mathrm{C}$ signatures for the purpose of paleo-reconstruction of vegetation distribution (Cerling and others 1988; Mora and others 2002; Santschi and others 2007; dos Santos and others 2013) may lead to significant overestimation of the areal $\mathrm{C}_{3}$ cover within drainage basins characterised by considerable expanses of $\mathrm{C}_{4}$ grassland.

\section{ACKNOWLEDGMENTS}

Funding for this work was provided by the European Research Council (ERC-StG 240002, AFRIV$\mathrm{AL}$, http://ees.kuleuven.be/project/afrival/). We kindly thank Rabeharisoa Lilia (LRI ESSA, Madagascar) for logistical support in the field, as well as Rabemanantsoa François, Rabemanantsoa Miharisoa and Mahatsindry Randzato Solo for consider- able assistance gathering field samples. We also thank Zita Kelemen (KU Leuven), Peter Salaets (KU Leuven), Benjamin Horemans (KU Leuven), Michael Korntheuer (VUB) and Peter van Breughel (NIOZ) for technical and laboratory assistance. Particular thanks to Christopher Still and Rebecca Powell for providing the GIS data layers of their isoscape models. A.V.B. is a senior research associate at the FRS-FNRS (Belgium). Two anonymous reviewers and the handling editor, S. Bunn, provided insightful and constructive comments on an earlier version of this manuscript.

\section{OPEN ACCESS}

This article is distributed under the terms of the Creative Commons Attribution License which permits any use, distribution, and reproduction in any medium, provided the original author(s) and the source are credited.

\section{REFERENCES}

Abrantes KG, Barnett A, Marwick TR, Bouillon S. 2013. Importance of terrestrial subsidies for estuarine food webs in contrasting East African catchments. Ecosphere 4:Article 14.

Abril G, Nogueira M, Etcheber H, Cabeçadas G, Lemaire E, Brogueira MJ. 2002. Behaviour of organic carbon in nine contrasting European estuaries. Estuar Coast Shelf Sci 54:24162.

Albéric P. 2011. Liquid chromatography/mass spectrometry stable isotope analysis of dissolved organic carbon in stream and soil waters. Rapid Commun Mass Spectrom 25:3012-18.

Aldegheri M. 1964. Monographie hydrologique de l'Ikopa et de la Betsiboka: Facteurs conditionnels du régime. Paris: ORSTOM.

Aldegheri M. 1972. Rivers and streams on Madagascar. In: Battistini R, Richard-Vindard G, Eds. Biogeography and ecology in Madagascar. Dordrecht: Springer. p 261-310.

Ballester MVR, Victoria RL, Krusche AV, Bernardes M, Neill C, Deegan L, Richey JE. 2013. Physical and human controls on the carbon composition of organic matter in tropical rivers: an integrated analysis of landscape properties and river isotopic composition. IAEA. Application of isotope techniques for assessing nutrient dynamics in rivers basins. Vienna: IAEA. pp 173-86.

Benstead JP, Pringle CM. 2004. Deforestation alters the resource base and biomass of endemic stream insects in eastern Madagascar. Freshw Biol 49:490-501.

Bernardes MC, Martinelli LA, Krusche AV, Gudeman J, Moreira M, Victoria RL, Ometto JPHB, Ballester MVR, Aufdenkampe AK, Richey JE, Hedges JI. 2004. Riverine organic matter composition as a function of land use changes, southwest Amazon. Ecol Appl 14(Supplement):S263-79.

Bird MI, Fyfe WS, Pinheiro-Dick D, Chivas AR. 1992. Carbon isotope indicators of catchment vegetation in the Brazilian Amazon. Glob Biogeochem Cycles 6:293-306.

Bird MI, Giresse P, Chivas AR. 1994. Effect of forest and savanna vegetation on the carbon-isotope composition from the Sanaga River, Cameroon. Limnol Oceanogr 39:1845-54. 
Bird MI, Pousai P. 1997. Variations of $\delta^{13} \mathrm{C}$ in the surface soil organic carbon pool. Glob Biogeochem Cycles 11:313-22.

Bird MI, Giresse P, Ngos S. 1998. A seasonal cycle in the carbonisotope composition of organic carbon in the Sanaga River, Cameroon. Limnol Oceanogr 43:143-6.

Bond WJ, Silander JA Jr, Ranaivonasy J, Ratsirarson J. 2008. The antiquity of Madagascar's grasslands and the rise of $\mathrm{C}_{4}$ grassy biomes. J Biogeogr 35:1743-58.

Boston HL, Hill WR. 1991. Photosynthesis-light relations of stream periphyton communities. Limnol Oceanogr 36:644-56.

Borchardt MA. 1996. Factors affecting benthic algae-nutrients. In: Stevenson RJ, Bothwell ML, Lowe RL, Eds. Algal ecology-freshwater benthic ecosystems. San Diego: Academic Press. p 184-227.

Bouillon S, Korntheuer M, Baeyens W, Dehairs F. 2006. A new automated setup for stable isotope analysis of dissolved organic carbon. Limnol Oceanogr 4:216-26.

Bouwman AF, Bierkens MFP, Griffioen J, Hefting MM, Middelburg JJ, Middelkoop H, Slomp CP. 2013. Nutrient dynamics, transfer and retention along the aquatic continuum from land to ocean: towards integration of ecological and biogeochemical models. Biogeosciences 10:1-23.

Bunn SE, Davies PM, Kellaway DM. 1997. Contributions of sugar cane and invasive pasture grass to the aquatic food web of a tropical lowland stream. Mar Freshw Res 48:173-9.

Burney D. 1987a. Pre-settlement vegetation changes at Lake Tritrivakely, Madagascar. Palaeoecol Afr Surround Isl 18:357-81.

Burney D. 1987b. Late Holocene vegetational change in central Madagascar. Quat Res 28:130-43.

Burney D. 1987c. Late Quaternary stratigraphic charcoal records from Madagascar. Quat Res 28:274-80.

Cerling TE, Bowman JR, O'Neil JR. 1988. An isotopic study of a fluvial-lacustrine sequence: the Plio-Pleistocene Koobi Fora sequence, East Africa. Palaeogeogr Palaeoclimatol Palaeoecol 63:335-56.

Chaperon P, Danioux J, Ferry L. 1993. Fleuves et rivières de Madagascar. Paris: ORSTOM. p 874p.

Ciais P, Bombelli A, Williams M, Piao SL, Chave J, Ryan CM, Henry M, Brender P, Valentini R. 2011. The carbon balance of Africa: synthesis of recent research studies. Philos Trans R Soc A 369:2038-57.

Claustre H, Hooker SB, Van Heukelem L, Berthon J-F, Barlow R, Ras J, Sessions H, Targa C, Thomas CS, van der Linde D, Marty JC. 2004. An intercomparison of HPLC phytoplankton pigment methods using in situ samples: application to remote sensing and database activities. Mar Chem 85:41-61.

Collatz GJ, Berry JA, Clark JS. 1998. Effects of climate and atmospheric $\mathrm{CO}_{2}$ partial pressure on the global distribution of $\mathrm{C}_{4}$ grasses: present, past, and future. Oecologia 114:441-54.

Cox R, Rakotondrazafy AFM, Bakoariniaina LN. 2003. Geological controls on development of erosional gullies (lavaka), central Madagascar. Geol Soc Am Abstr 35(6):p64.

Cox R, Rakotondrazafy AFM, Rakotondramazava HT. 2004. Geological versus human controls on lavaka formation and extreme erosion in Madagascar. Geol Soc Am Abstr 36(5):p171.

Cox R, Bierman P, Jungers MC, Rakotondrazafy AFM. 2009. Erosion rates and sediment sources in Madagascar inferred from ${ }^{10} \mathrm{Be}$ analysis of lavaka, slope and river sediment. J Geol 117:363-76.
Crowley BE, Thorén S, Rasoazanabary E, Vogel ER, Barrett MA, Zohdy S, Blanco MB, McGoogan KC, Arrigo-Nelson SJ, Irwin MT, Wright PC, Radespiel U, Godfrey LR, Koch PL, Dominy NJ. 2011. Explaining geographical variation in the isotope composition of mouse lemurs (Microcebus). J Biogeogr 38:2 106-21.

Davies PM, Bunn SE, Hamilton SK. 2008. Primary production in tropical streams and rivers. In: Dudgeon D, Ed. Tropical stream ecology. London: Academic Press. p 23-43.

Downing JA, McClain M, Twilley R, Melack JM, Elser J, Rabalais NN, Lewis WM, Turner RE, Corredor J, Soto D, Yanez-Arancibia A, Kopaska JA, Howarth RW. 1999. The impact of accelerating land-use change on the $\mathrm{N}$-cycle of tropical aquatic ecosystems: current conditions and projected changes. Biogeochemistry 46:109-48.

dos Santos RAL, De Deckker P, Hopmans EC, Magee JW, Mets A, Damsté JSS, Schouten S. 2013. Abrupt vegetation change after the Late Quaternary megafaunal extinction in southeastern Australia. Nat Geosci 6:627-31.

Du Puy DJ, Moat J. 1996. A refined classification of the primary vegetation of Madagascar based on the underlying geology: using GIS to map its distribution and to assess its conservation status. In: Lourenço WR, Ed. Biogeographie de Madagascar. Paris: ORSTOM. p 205-218 + 3 maps.

Du Puy DJ, Moat J. 1999. Vegetation mapping and biodiversity conservation in Madagascar Geographical Information Systems. In: Timberlake J, Kativu S, Eds. African plants: biodiversity taxonomy and uses. Kew: Royal Botanic Gardens. p 245-51.

Ehleringer JR. 1978. Implications of quantum yield differences to the distributions of $\mathrm{C}_{3}$ and $\mathrm{C}_{4}$ grasses. Oecologia 31:255-67.

Ehleringer JR, Björkman O. 1977. Quantum yields for $\mathrm{CO}_{2}$ uptake in $\mathrm{C}_{3}$ and $\mathrm{C}_{4}$ plants: dependence on temperature, $\mathrm{CO}_{2}$ and $\mathrm{O}_{2}$ concentrations. Plant Physiol 59:86-90.

Ehleringer JR, Cerling TE, Helliker BR. 1997. $C_{4}$ photosynthesis, atmospheric $\mathrm{CO}_{2}$, and climate. Oecologia 112:285-99.

Elouard J-M. 2001. Éco-hydrosystèmes. In: Gibon F-M, Elouard J-M, Eds. Biodiversité et biotypologie des eaux continentals de Madagascar. Marseille: Institut de Recherche pour le Développement (IRD). p 37-50.

Feminella JW, Power ME, Resh VH. 1989. Periphyton responses to invertebrate grazing and riparian canopy in three northern California coastal streams. Freshw Biol 22:445-57.

Findlay S. 2010. Stream microbial ecology. J N Am Benthol Soc 29:170-81.

Finlay JC, Kendall C. 2007. Stable isotope tracing of temporal and spatial variability in organic matter sources to freshwater ecosystems. In: Michener RH, Lajtha K, Eds. Stable isotopes in ecology and environmental science. 2nd edn. Malden: Blackwell. p 283-333.

Flecker AS, Taylor BW, Bernhardt ES, Hood JM, Cornwell WK, Cassatt SR, Vanni MJ, Altman NS. 2002. Interactions between herbivorous fishes and limiting nutrients in a tropical stream ecosystem. Ecology 83:1831-44.

Gillikin DP, Bouillon S. 2007. Determination of $\delta 180$ of water and $\delta 13 \mathrm{C}$ of dissolved inorganic carbon using a simple modification of an elemental analyser-isotope ratio mass spectrometer: an evaluation. Rapid Commun Mass Spectrom 21:1475-8.

Hama T, Miyazaki T, Ogawa Y, Iwakuma T, Takahashi M, Otsuki A, Ichimura S. 1983. Measurement of photosynthetic production 
of a marine phytoplankton population using a stable ${ }^{13} \mathrm{C}$ isotope. Mar Biol 73:31-6.

Hamilton SK, Lewis WM Jr. 1992. Stable carbon and nitrogen isotopes in algae and detritus from the Orinoco River floodplain, Venezuela. Geochim Cosmochim Acta 56:4237-46.

HarvestChoice. 2011. Sugar cane area harvested (ha) (2000). Washington, DC and St. Paul, MN: International Food Policy Research Institute and University of Minnesota. http:// harvestchoice.org/node/5065. Accessed 10 Feb 2014.

Hedges JI, Clark WA, Quay PD, Richey JE, Devol AH, de M Santos U. 1986. Compositions and fluxes of particulate organic material in the Amazon River. Limnol Oceanogr 31:717-38.

Hill WR, Ryon MG, Schilling EM. 1995. Light limitation in a stream ecosystem: responses by primary producers and consumers. Ecology 76:1297-309.

Kendall C, Silva SR, Kelly VJ. 2001. Carbon and nitrogen isotopic compositions of particulate organic matter in four large river systems across the United States. Hydrol Process 15:1301-46.

Kohn MJ. 2010. Carbon isotope compositions of terrestrial $C_{3}$ plants as indicators of (paleo) ecology and (paleo) climate. Proc Natl Acad Sci 107:19691-5.

Kull CA. 2004. Isle of fire: the political ecology of landscape burning in Madagascar. Chicago: University of Chicago Press.

Kull CA. 2012. Fire and people in tropical island grassland landscapes: Fiji and Madagascar. J Pac Stud 32:121-9.

Lehsten V, Tansey K, Balzter H, Thonicke K, Spessa A, Weber U, Smith B, Arneth A. 2009. Estimating carbon emissions from African wildfires. Biogeosciences 6:349-60.

Lewis WM Jr, Hamilton SK, Rodríguez MA, Saunders JFIII, Lasi MA. 2001. Foodweb analysis of the Orinoco floodplain based on production estimates and stable isotope data. J N Am Benthol Soc 20:241-54.

Lloyd J, Bird MI, Vellen L, Miranda AC, Veenendaal EM, Djagbletey G, Miranda HS, Cook G, Farquhar GD. 2008. Contributions of woody and herbaceous vegetation to tropical savanna ecosystem productivity: a quasi-global estimate. Tree Physiol 28:451-68.

Lorenzen CJ. 1967. Determination of chlorophyll and pheopigments: spectrophotometric equations. Limnol Oceanogr $12: 343-6$.

Ludwig W, Probst JL, Kempe S. 1996. Predicting the oceanic input of organic carbon by continental erosion. Glob Biogeochem Cycles 10:23-41.

Mariotti A, Gadel F, Giresse P. 1991. Carbon isotope composition and geochemistry of particulate organic matter in the Congo River (Central Africa): application to the study of Quaternary sediments off the mouth of the river. Chem Geol Isot Geosci Sect 86:345-57.

Marwick TR, Tamooh F, Ogwoka B, Teodoru C, Borges AV, Darchambeau F, Bouillon S. 2014. Dynamic seasonal nitrogen cycling in response to anthropogenic N-loading in a tropical catchment, Athi-Galana-Sabaki River, Kenya. Biogeosciences 11:443-60.

Menaut JC, Gignoux J, Prado C, Clobert J. 1990. Tree community dynamics in a humid savannah of the Cote-d'Ivoire: modelling the effects of fire and competition with grass and neighbours. J Biogeogr 17:471-81.

Meybeck M. 1993. C, N, P and S in rivers: from sources to global inputs. In: Wollast R, Mackenzie FT, Chou L, Eds. Interaction of C, N, P and S: biogeochemical cycles and global change. Berlin: Springer. p 163-93.

Mora G, Pratt LM, Boom A, Hooghiemstra H. 2002. Biogeochemical characteristics of lacustrine sediments reflecting a changing alpine neotropical ecosystem during the Pleistocene. Quat Res 58:189-96.

Mosisch TD, Bunn SE, Davies PM, Marshall CJ. 1999. Effects of shade and nutrient manipulation on periphyton growth in a subtropical stream. Aquat Bot 64:167-77.

Mosisch TD, Bunn SE, Davies PM. 2001. The relative importance of shading and nutrients on algal production in subtropical streams. Freshw Biol 46:1269-78.

Peterson BJ, Hobbie JE, Corliss TL, Kriet K. 1983. A continuousflow periphyton bioassay: tests of nutrient limitation in a tundra stream. Limnol Oceanogr 28:583-91.

Pringle CM, Paaby-Hansen P, Vaux PD, Goldman CR. 1986. In situ nutrient assays of periphyton growth in a lowland Costa Rican stream. Hydrobiologia 134:207-13.

Ralison OH, Borges AV, Dehairs F, Middelburg JJ, Bouillon S. 2008. Carbon biogeochemistry of the Betsiboka estuary (north-western Madagascar). Org Geochem 39:1649-58.

Ranalli AJ, Macalady DL. 2010. The importance of the riparian zone and in-stream processes in nitrate attenuation in undisturbed and agricultural watersheds: A review of the scientific literature. J Hydrol 389:406-15.

Remington SM, Strahm BD, Neu V, Richey JE, da Cunha HB. 2007. The role of sorption in control of riverine dissolved organic carbon concentrations by riparian zone soils in the Amazon Basin. Soil Sci 172:279-91.

Reynolds CS. 2006. The ecology of phytoplankton. Cambridge: Cambridge University Press. p 552p.

Santschi PH, Oktay SD, Cifuentes L. 2007. Carbon isotopes and iodine concentrations in a Mississippi River delta core recording land use, sediment transport, and dam building in the river's drainage basin. Mar Environ Res 63:278-90.

Still CJ, Powell RL. 2010. Continental-scale distributions of vegetation stable carbon isotope ratios. In: West $\mathrm{JB}$, Bowen GJ, Dawson TE, Tu KP, Eds. Isoscapes. Dordrecht: Springer. $p$ 179-93.

Tamooh F, Van den Meersche K, Meysman F, Marwick TR, Borges AV, Merckx R, Dehairs F, Schmidt S, Nyunja J, Bouillon S. 2012. Distribution and origin of suspended sediments and organic carbon pools in the Tana River Basin, Kenya. Biogeosciences 9:2905-20.

Torello-Raventos M, Feldpausch TR, Veenendaal E, Schrodt F, Saiz G, Domingues TF, Djagbletey G, Ford A, Kemp J, Marimon BS, Marimon Júnior BH, Lenza E, Ratter JA, Maracahipes L, Sasaki D, Sonké B, Zapfack L, Taedoumg H, Villarroel D, Schwarz M, Quesada CA, Ishida FY, Nardoto GB, Affum-Baffoe K, Arroyo L, Bowman DMJS, Compaore H, Davies K, Diallo A, Fyllas NM, Gilpin M, Hien F, Johnson M, Killeen TJ, Metcalfe D, Miranda HS, Steininger M, Thomson J, Sykora K, Mougin E, Hiernaux P, Bird MI, Grace J, Lewis SL, Phillips OL, Lloyd J. 2013. On the delineation of tropical vegetation types with an emphasis on forest/savanna transitions. Plant Ecol Divers 6:101-37.

Udy J, Dennison WC. 2005. Nutrients. In: Bunn SE, Dennison WC, Abal EG, Eds. Healthy waterways, healthy catchments: making the connection in South East Queensland. Brisbane: Moreton Bay and Catchments Partnership. p 93-118.

USAID. 1998. USAID congressional presentation FY 1998 Washington, DC: USAID. 
Valentini R, Arneth A, Bombelli A, Castaldi S, Cazzolla Gatti R, Chevallier F, Ciais P, Grieco E, Hartmann J, Henry M, Houghton RA, Jung M, Kutsch WL, Malhi Y, Mayorga E, Merbold L, Murray-Tortarolo G, Papale D, Peylin P, Poulter B, Raymond PA, Santini M, Sitch S, Vaglio Laurin G, van der Werf GR, Williams CA, Scholes RJ. 2014. A full greenhouse gases budget of Africa: synthesis, uncertainties, and vulnerabilities. Biogeosciences 11:381-407.

Vannote RL, Minshall GW, Cummins KW, Sedell JR, Cushing CE. 1980. The river continuum concept. Can J Fish Aquat Sci 37:130-7.

Wells NA, Andriamihaja B. 1993. The initiation and growth of gullies in Madagascar: are humans to blame? Geomorphology 8:1-46.

Wells NA, Andriamihaja B. 1997. Extreme gully erosion in Madagascar and its natural and anthropogenic causes. In: Goodman SM, Patterson BD, Eds. Natural change and human impact in Madagascar. Washington, DC: Smithsonian Institution Press. p 44-74.
Wells NA, Andriamihaja B, Rakotovololona HFS. 1991. Patterns of development of lavaka, Madagascar's unusual gullies. Earth Surf Proc Land 16:189-206.

Winterbourn MJ. 1990. Interactions among nutrients, algae and invertebrates in a New Zealand mountain stream. Freshw Biol 23:463-74

World Bank. 1998. Analysis and advisory work report E21. Madagascar: environmental action plan, Vol. IWashington, DC: World Bank.

Wright SW. 1991. Improved HPLC method for the analysis of chlorophylls and carotenoids from marine phytoplankton. Mar Ecol Prog Ser 77:183-96.

Wynn JG, Bird MI. 2007. $C_{4}$-derived soil organic carbon decomposes faster than its $\mathrm{C}_{3}$ counterpart in mixed $\mathrm{C}_{3} / \mathrm{C}_{4}$ soils. Glob Change Biol 13:2206-17.

Zavada MS, Wang Y, Rambolamanana G, Raveloson A, Razanatsoa H. 2009. The significance of human induced and natural erosion features (lavakas) on the central highlands of Madagascar. Madag Conserv Dev 4:120-7. 